\title{
Din Eğitimi Öğretmenlerinin Bilgi ve Dini Bilgi Anlayışları
}

\section{Cemal Tosun}

Prof. Dr., Ankara Üniversitesi (ROR ID: 01wntqw50)

İlahiyat Fakültesi Felsefe ve Din Bilimleri Bölümü Din Eğitimi Anabilim Dalı

Professor, Ankara University, Divinity Faculty,

Philosophy and Religious Sciences, Religious Education Department

Ankara/Turkey

cemaltos@gmail.com

ORCID: 0000-0002-9941-4769

\section{Gülşen Sayın}

Dr. Arş. Gör., İnönü Üniversitesi (ROR ID: 04asck240)

İlahiyat Fakültesi, Felsefe ve Din Bilimleri Bölümü Din Eğitimi Anabilim Dalı

Res. Asst. Ph.D., İnonu University, Divinity Faculty,

Philosophy and Religious Sciences, Religious Education Department

$$
\begin{gathered}
\text { Malatya/Turkey } \\
\text { gulsensayin@hotmail.com } \\
\text { ORCID: 0000-0002-9214-7573 }
\end{gathered}
$$

\section{Understanding of Knowledge and Religious Knowledge of Religious Education Teachers Abstract}

Religious knowledge has an encompassing dimension in the mental worlds and lives of individuals on the axis of beliefs. Religious knowledge does not only exist in terms of worship for believers, but it can also be a guide for the whole of life. Religious knowledge is frequently referenced in actions in daily life. In this respect, religious knowledge has a system that organizes daily life for individuals and realizes this through its worldview. The dimension of religious knowledge that comes to the fore in teaching processes also directly affects the worldview of religion and to what extent it reflects it. Although religious education in the education system is an educational activity that is handled with teaching methods and techniques, teac-

Bu çalışma "Din Dersleri Öğretmenlerinin Dini Bilgi Anlayışları ve Bunun Din Öğretimine Yansıması" başlıklı doktora tez çalışması esas alınarak hazırlanmıştır. / This study has been prepared on the basis of the dissertation titled "Religious Knowledge Understanding of Religion Lessons Teachers and Its Reflection on Religious Education"

Intihal Taraması/Plagiarism Detection: Bu makale intihal taramasından geçirildi/This paper was checked for plagiarism Etik Beyan/Ethical Statement: Bu çalışmanın hazırlanma sürecinde bilimsel ve etik ilkelere uyulduğu ve yararlanılan tüm çalışmaların kaynakçada belirtildiği beyan olunur/It is declared that scientific and ethical principles have been followed while carrying out and writing this study and that all the sources used have been properly cited (Cemal Tosun, Gülşen Sayın).

Geliş/Received: 25 Mayıs/May 2021 | Kabul/Accepted: 14 Temmuz/July 2021 | Yayın/Published: 20 Eylül/September 2021 Atıf/Cite as: Cemal Tosun, Gülșen Sayın, "Din Eğitimi Öğretmenlerinin Bilgi ve Dini Bilgi Anlayışları = Understanding of Knowledge and Religious Knowledge of Religious Education Teachers", Eskiyeni 45 (Eylül/September 2021), 753-779. https://doi.org/10.37697/eskiyeni.942405

CC BY-NC 4.0 | This paper is licensed under a Creative Commons Attribution-NonCommercial License 
hers can shape religious education processes with their understanding of religious knowledge. It can be said that religious education teachers' understanding of religious knowledge affects what kind of religious teaching approach is adopted in religious teaching and the teaching methods and techniques used. Therefore, religious education teachers' understanding of knowledge and religious knowledge emerges as an element that shapes the boundaries of religious education processes in addition to the adopted educational philosophy, curriculum and content.

In this study, it was aimed to examine the knowledge and religious knowledge understanding of the Religious Culture and Morals Knowledge (RCMK) course teachers and the vocational courses teachers at the Anadolu Imam Hatip High Schools (AIHHS) through their views. The working group consists of 21 RCMK teachers and AIHHS vocational courses teachers. Qualitative research method and interview technique was used in the study. The data were collected through interviews consisting of semi-structured questions. Content analysis was applied to the data obtained. In the research, the theme of "teachers understanding of knowledge and religious knowledge" has been discussed under the categories of "knowledge understandings, sources of religious knowledge" and "the distinction between knowledge and religious knowledge". According to the results of the study, teachers evaluate knowledge and religious knowledge in the axis of Islamic knowledge. Therefore, knowledge and religious knowledge were handled by participants with a holistic approach. However, participants kept separate religious knowledge from other knowledge by emphasizing its functionality. Participants' understood religious knowledge in practice, in a way that encompasses the whole of life and all knowledge. Participants evaluated knowledge on the basis of religious knowledge. In this sense, the participants' understanding of religious knowledge includes their understanding of knowledge. In addition, based on the fact that religious knowledge is based on revelation, a separate sanctity, superiority and value has been attributed to religious knowledge compared to other knowledge.

\section{Keywords}

Religious Education, RCMK Teachers, AIHHS Vocational Course Teachers, Understanding of Knowledge, Understanding of Religious Knowledge

\section{Öz}

Dini bilgi sahip olunan inançlar ekseninde bireylerin zihin dünyaları ve hayatlarında kuşatıcı bir boyuta sahiptir. Dini bilgi inanan bireyler için yalnızca ibadet boyutu ile varlık göstermez aynı zamanda hayatın bütünü için de yönlendirici olabilmektedir. Günlük yaşantıdaki eylemlerde de dini bilgiye sıklıkla referans yapılmaktadır. Dini bilgi bu yönüyle bireyler için günlük yaşamı düzenleyen ve bunu da sahip olduğu dünya görüşü üzerinden gerçekleștiren bir sisteme sahiptir. Dini bilginin öğretim süreçlerinde ön plana çıkan boyutu, dinin sahip olduğu dünya görüşünü ve bunu ne düzeyde yansıttığını da doğrudan etkilemektedir. Eğitim sistemi içerisinde yer alan din öğretimi her ne kadar öğretim yöntem ve teknikleri ile ele alınan bir eğitim faaliyeti olsa da öğretmenler sahip oldukları dini bilgi anlayışları ile din öğretimi süreçlerini şekillendirebilmektedirler. Denilebilir ki din eğitimi öğretmenlerinin dini bilgi anlayışları din öğretim süreçlerinde nasıl bir din öğretimi yaklaşımı benimsendiğini ve kullanılan öğretim yöntem ve tekniklerini etkilemektedir. Bu anlamda din eğitimi öğretmenlerinin bilgi ve dini bilgi anlayışları benimsenen eğitim felsefesi, müfredat ve içeriğe ek olarak din öğretimi süreçlerinin sınırlarını şekillendiren bir unsur olarak karşımıza çıkmaktadır. 
Bu araştırmada, Din Kültürü ve Ahlak Bilgisi dersi öğretmenleri ile Anadolu imam hatip lisesi meslek dersi öğretmenlerinin, kendi görüşleri üzerinden, bilgi ve dini bilgi anlayışlarının ortaya konulması hedeflenmiştir. Araştırma grubu Malatya ili merkez ilçelerinde görev yapan toplam 21 Din Kültürü ve Ahlak Bilgisi dersi öğretmeni ile Anadolu imam hatip lisesi meslek dersi öğretmenlerinden oluşmaktadır. Araştırmada nitel araştırma yöntemi, veri toplamada ise mülakat tekniği kullanılmıştır. Veriler, yarı yapılandırılmış sorulardan oluşan mülakatlar ile toplanmıştır. Elde edilen verilere içerik analizi uygulanmıştır. Araştırmada "öğretmenlerin bilgi ve dini bilgi anlayışları" teması; "bilgi anlayışları, dini bilgi kaynakları" ve "bilgi ve dini bilgi ayrımı" kategorileri altında ele alınmıştır. Araştırmanın sonuçlarına göre öğretmenler bilgi ve dini bilgiyi İslam bilgi anlayışı ekseninde değerlendirmektedirler. Bu bağlamda bilgi ve dini bilgi katılımcılar tarafından bütüncül bir yaklaşım ile ele alınmıştır. Ancak dini bilgi diğer bilgilerden, işlevselliği vurgulanarak ayrı tutulmuştur. Katılımcılara göre dini bilgi uygulamada, hayatın bütününü ve bütün bilgileri içine almaktadır. Katılımcılar bilgiyi dini bilgileri temelinde değerlendirmişlerdir. Bu anlamda katılımcıların dini bilgi anlayışları bilgi anlayışlarını kapsamaktadır. Ayrıca dini bilginin vahiy kaynaklı oluşu üzerinden ona diğer bilgilere nispi olarak ayrı bir kutsallık, üstünlük ve değer yüklenmiştir.

\section{Anahtar Kelimeler}

Din Eğitimi, DKAB Öğretmenleri, AïHL Meslek Dersi Öğretmenleri, Bilgi Anlayışı, Dini Bilgi Anlayışı

\section{Giriş}

Eğitim ve din bireyin dünya görüşünü şekillendiren temel unsurlardandır. Din, insanlığa seslenerek onların hayat, insan ve evren üzerindeki düşüncelerini şekillendirir. Eğitim ise benimsemiş olduğu felsefi anlayış ile insanın, hayata ve doğaya ilişkin görüşlerinin, kısaca dünya görüşünün gelişmesine katkı sunmaktadır. Buradan hareketle din eğitiminin insan düşünce ve yaşayışı üzerinde belirleyici etkisinden söz edilebilir. Eğitim ve dinin birey üzerindeki bu etkisini, kazandırmayı hedefledikleri bilgilere atfetmek mümkündür. Bu durum din eğitimi açısından değerlendirildiğinde bilgi ve dini bilgi ile onu anlama biçimleri farklı bir önem kazanmaktadır. Çünkü din eğitiminin formasyonu yalnızca belirlenen sınırlar içerisindeki süreç ve prosedür ile sınırlı olmayıp bu bilgiyi nakleden öğretmenler de benimsemiş oldukları dini bilgi anlayışları ile öğrenim süreçlerine dâhil olmaktadırlar. Bir yönüyle din eğitimi öğretmenlerinin sahip oldukları dünya görüşleri de öğretim süreçlerine dahil olmaktadır. Bu açıdan din eğitimi öğretmenlerinin nasıl bir bilgi ve dini bilgi anlayışına sahip oldukları, doğrudan öğretim süreçlerine dahil olmaları nedeniyle benimsenen eğitim felsefesi, müfredat ve içerikten daha önemli bir hal almaktadır. Çünkü bu anlayışın, din eğitimine yansıması kuvvetle muhtemeldir.

Din öğretimi süreçlerinde "öğretilen dini bilginin öğreticileri tarafından nasıl anlaşıldığı?” sorusu bu araştırmanın konusunu teşkil etmektedir. Çünkü din eğitimi öğretmenlerinin sahip oldukları dini bilgi anlayışlarının öğretim süreçlerine de yansıdığı düşünülmektedir. Araştırmada bilgi ve dini bilgi hakkında literatüre dayalı olarak genel bir çerçeve çizildikten sonra din eğitimi öğretmenlerinin bilgi ve dini bilgi anlayışları kendi görüşleri üzerinden ele alınmaya çalışılmıştır. 


\section{Yöntem}

Araştırma nitel desenlidir. Veri toplamada teorik kısımda literatür taraması, alan araştırmasında ise yarı yapılandırılmış mülakat tekniği kullanılmıştır. Yarı yapılandırılmış mülakat formu oluşturulurken uzman görüşlerinden yararlanılmış ve pilot uygulamalar yapılmıştır. Etik kuruldan izin alınmış ve veri toplamada gönüllülük ilkesine riayet edilmiştir. Bu yönde talebi olanlara mülakat dökümleri ulaştırılarak onayları alınmıştır. Mülakatlar verilerde doyuma ulaşılıncaya kadar sürdürülmüştür.

Nitel yöntemin kullanıldığı bu çalışmada bireysel deneyimler ön plana çıktığı için fenomonolojik yaklaşım tercih edilmiştir. Fenomenolojik yaklaşıma göre; geliştiği varlık alanına göre şekillenen bilgi anlayışı yere, zamana ve içinde geliştiği kültüre ve diline göre değişim gösterir. Bu anlamda bir olguya ilişkin tek bir bilgi anlayışının varlığından söz edilemez. ${ }^{1}$ Fenomenolojinin amacı bilgi ve nesneleri arasında bulunan yapay bağı yıkarak aradaki organik bağın görünürlüğünü arttırmaktır. ${ }^{2}$ Bu yaklaşım, görünenin bağımsız değeri (value free) ile dinlerin özünü inceleyen bir yoldur. Bu özel bir yöntem olmanın ötesinde dini çalışmalar için bir yaklaşımdır. ${ }^{3}$ Bu yaklaşım temelinde katılımcıların görüşlerine yalnızca bir söylem olarak bakılmamış betimsel değil içerik analizi uygulanarak arka plan okumaları yapılmaya çalışılmıştır.

\section{1. Çalışma Grubu}

Araştırmanın çalışma grubu, Malatya il merkezi ve merkez ilçelerinde görev yapan 21 DKAB ve AİHL meslek dersi öğretmeninden oluşmaktadır. Çalışma grubunun seçilmesinde maksimum çeşitlilik örneklem ilkeleri dikkate alınmıştır. Araştırmada alternatif bakış açıları yakalanması ve maksimum çeşitlilik sağlanması amacıyla çalışma grubu; farklı okullarda, farklı derslerde deneyimli, farklı cinsiyetlerde, farklı yaşlardan ve özellikle farklı mesleki tecrübeye sahip öğretmenlerden seçilmiştir (Ek 1). ${ }^{4}$ Katılımcılar 26 ile 56 yaş aralığındadır. Katılımcılardan 8'i kadın 13'ü erkektir. 6 farklı okulda, DKAB ve AİHL meslek dersi öğretmenleri olarak gerek yoğun teoloji bilgisi gerekse manevi boyutu besleyen dini bilginin farklı formlarının yer aldığı öğretim süreçlerinde görev yapmaktadırlar. Veri toplama aracı için etik kurul' ${ }^{5}$, uygulama için ile İl Milli Eğitim Müdürlüğün$\operatorname{den}^{6}$ gerekli izinler alınmıştır. Ayrıca araştırma için katılımcılara gönüllü onam formu imzalatılmıştır.

\footnotetext{
Peter Burke, Bilgi Tarihi Nedir?, çev. Turgay Sivrikaya (İstanbul: Islık Yayınları, 2018), 21.

Erhan Güngör (ed. ), Çağdaş Epistemolojiye Giriş (İstanbul: İnsan Yayınları, 2011), 57.

Ursula King, "Historical and Phenomenological Approaches" Contemporary Approaches to The Study of Religion, ed. Frank Whaling (New York, Amsterdam: Mouton Publishers, 1984), 36-39.

4 Micheal Quinn Patton, Nitel Araştırma ve Değerlendirme Yöntemleri, çev. Mesut Bütün - Selçuk Beşir Demir (Ankara: Pegem Akademi Yayıncilık, ts.), 235.

5 Ankara Üniversitesi Rektörlüğü 05.11.2018 tarihli ve 13/72 nolu karar.

6 Malatya İl Milli Eğitim Müdürlüğü 05.11.2018 tarihli ve 61316174-44-E 12874756 nolu karar.
} 


\subsection{Verilerin Toplanması ve Analizi}

Veri toplama aracı olarak kullanılan yarı yapılandırılmış görüşme formu toplamda 9 soru ve onu açımlayıcı nitelikteki sonda sorulardan oluşmuştur. Elde edilen veriler yukarıda belirtilmiş olan tezde kullanılmış ve bu çalışmada araştırmanın yalnızca bir boyutuna karşılık gelen, öğretmenlerin bilgi ve dini bilgiye yönelik görüşlerine ait analizler sunulmuştur. Katılımcılara yöneltilen sorulardan yalnızca; "Bilgi kavramı size ne ifade eder? Dini bilgi hakkında neler düşünüyorsunuz? Sizce dini bilginin diğer bilgilerden farkı var mıdır? (Kaynak vs...)" sorularına alınan cevaplardan tek bir tema ve alt kategorileri oluşturulmuştur.

Mülakatlardan elde edilen veriler çözümlenerek metne dönüştürülmüştür. Metinler tümdengelim ve tümevarım yaklaşımları birlikte kullanılarak kodlamaya tabi kılınmıştır. Kodlamalardan alt kategoriler ve kategorilere ulaşılmıştır. Analiz işlemleri için Nvivo 10 programı kullanılmıştır. İçerik analizinin yapıldığı araştırmada tema ve kategorilere ulaşılırken öncelikle başlangıç kodları oluşturulmuştur. Verilerin analiz sürecinde fenomenolojik bir yaklaşım benimsenmiştir. Böylelikle, katılımcıların dini bilgiye yönelik kişisel görüşleri sentez örüntüleri ile birlikte anlamlı bir ilişki içerisinde sunulmuştur.

\section{Teorik Çerçeve: Bilgi ve Dini Bilgi}

Bilginin neliği ve niteliğinin ele alınışında iki farklı boyut ön plana çıkmaktadır. Bunlar; insan doğasının kökenlerindeki arayışta ulaşılan bilginin tarihsel yönü ve bununla özdeşleşmiş hakikat arayışı şeklindedir. Bu iki yaklaşımdan ilki, bilginin salt bir hakikat kovalamacası olmayıp insanlığın devamı için stratejik bir olgu, hakikatin ise bilginin bir unsuru olmayıp sonradan ortaya çımış bir illet/ilinti oluşuna ilişkin iddiadır. Diğeri ise bilginin aslında hakikat arayışı olduğu iddiasıyla ön plana çıkan metafiziksel yaklaşımdır. ${ }^{7}$ Dini bilginin felsefi temelde ele alınışının daha çok hakikat kavramı ekseninde şekillendiği söylenebilir. Bilgi ve dini bilgi arasındaki ilişkiyi de bu bağlamda değerlendirmek mümkündür.

Dini bilgi kavramı en yalın ve genel haliyle dine yönelik doğru veya ilkesel/sistematik olarak doğruluğu ispatlarıyla ortaya konulabilecek önermelere referansta bulunan bir bilgi türüdür. ${ }^{8}$ Aslında önemli olan dinsel ifade veya dini bilginin dini olup olmadığına ilişkin bir sınanma durumu değil, bu ifadelerin insan hayatında icra ettiği rol, fonksiyonu ve insanın anlam dünyasına katkısıdır. Eğer bir inanç bağlanma duygusuna ilişkin bir obje olma koşulu ile varlık ve işlevsellik gösteriyorsa ve kendisine kapsamlı bir yöneliş durumu söz konusu ise bu olgu dinsel bir özellik taşımaktadır. ${ }^{9} \mathrm{Bu}$

7 Michel Foucault, Bilme İstenci Üzerine Dersler Collège de France Dersleri, çev. Kerem Eksen (ìstanbul: İstanbul Bilgi Üniversitesi Yayınları, 2016), 18-19.

8 Mehmet S. Reçber, "Dini İnanç ve Dini Bilgi Kavramları Üzerine", Diriliş Yolunda Türk Düşüncesi Necati Öner'e Armağan, ed. Bahaeddin Yediyıldız (Ankara: Türk Kültürünü Araştırma Enstitüsü Yayınları, 2013), 263-274.

9 Williame T. Blackstone, Dinsel Bilgi Sorunu: Felsefi Çözümlemelerin Dinsel Bilgi Sorununa Etkileri, çev. Tuncay İmamoğlu (İstanbul: Ataç Yayınları, 2005), 52. 
açıdan dini bilgi daha çok yaşama yansıyan yönleri ile görünürlük ve tartışma alanı kazanmaktadır. Dini bilginin epistemolojik ve teolojik zemindeki tartışmalarının yanı sıra din eğitimi bilimine konu olan dini bilginin neliği sorusu da din eğitiminin genel ve temel tartışmalarından biridir. Ancak din öğretiminde dini bilginin neliğini belirleyen unsurlar, yalnızca epistemoloji ve teoloji eksenindeki ele alınış ile değil, din eğitimi uygulamalarında süreç içerisinde ön plana çıkan yaklaşımlar ve dini bilgi anlayışları da olabilmektedir.

Dinlerin ön plana çıan yedi ortak boyutu bulunmaktadır. Dini bilginin sistematiği olarak da nitelendirilebilecek bu boyutları; öğreti boyutu (doctrinal dimension); nihai gerçeklik/ïlahi olan ile beşer arasındaki ilişkiye dairdir. Ayrıca her din metaforik anlatım ve hikayelere dayanır ve bu, dinin efsane boyutunu (mythological dimension) oluşturur. Dinin hayata dair ahlaki fiiller ile ahlaki boyutu (ethical dimension), emredilen davranışlara ilişkin ayin boyutu (ritual dimension) ve her dinin birey ve toplum hayatındaki görünür yönü olan tecrübe boyutu (experiential dimension), bireyler arasındaki ilişkileri düzenleyen sosyal boyutu (social dimension) tanrı veya tanrıların fiziki dünyadaki yansıması olan dinin maddi boyutu (material dimension ${ }^{10}$ şeklinde betimlemek mümkündür. Wan Daud dinin boyutlarını İslam özelinde; beşerî olaylar ve inanç, ritüel, ibadet ve ahlaki davranış şeklinde gruplandırmaktadır. ${ }^{11}$ Dini bilginin öğretim süreçlerinde bu boyutların hangisinin ele alındığı benimsenen dini bilgi anlayışını da etkileyebilmektedir. Örneğin dinin öğreti boyutlarında normatif bir dini bilgi anlayışının varlığı olağandır. Bu durum dini bilginin öğretiminde var olan dini öğrenme, dinden öğrenme, din hakkında öğrenme gibi din öğretimi yaklaşımlarını da yönlendirebilmektedir. Böylelikle dersin içeriği ve öğretmenlerin sahip oldukları inanç ve dini bilgi anlayışları, dini bilginin öğretim süreçlerinde öğretim yöntemlerine ilişkin karar verme durumlarında etken unsurlar olarak karşımıza çıkmaktadır.

Din eğitiminde dini bilginin ele alınışı "hangi bilginin kime, ne kadar öğretileceği” sorusu ile de yakından ilişkilidir. Öğretmenlerin öğretim alanlarından hangisini, ne kadar vereceği noktasında ise öğretmeninin dini bilgi anlayışı başta olmak üzere öğrencilerin hazırbulunuşluk ve sosyokültürel durumları, dersin niteliği (meslek veya DKAB dersi olması), dersin konusu ve amaçları belirleyici olmaktadır. Dini bilginin öğretiminde öğretilmek istenen dinin ne olduğu kadar öğretmen ve öğrencinin o dine ilişkin ortaya konulan anlayış ve yüklemiş oldukları anlamlar da önem kazanmaktadır. Öğrencinin dini bilgiden ne anladığı öğretmenin dini bilgiyi sunuş şekli ve dini bilgiye yaklaşımı ile yakından ilgilidir. Bu durum öğrencinin ne bildiğinden daha çok o bilgiden ne anladığını ve nasıl bir anlam yüklediğini daha önemli hale getirmektedir. ${ }^{12}$ Dini anlayışı da karşılayan bu durum bağlamsal değişkenliğe sahip-

10 Michael Peterson vd., Akll ve İnanç: Din Felsefesine Giriș (ìstanbul: Küre Yayınları, 2015), 22.

11 W. M. Nor Wan Daud, İslam bilgi Anlayışı ve Çoğulcu Bir Toplumun Eğitim Sistemine Yansıması Malezya Örneği, çev. Fuat Aydın (Ankara: Ankara Okulu Yayınları, 2002), 77-78.

12 Walshe - Teece, “Understanding 'Religious Understanding' in Religious Education”, 313-325. 
tir. Bu anlamda din öğretiminin başlangıç noktası olan dini bilginin neliği ve dini bilgiye tutumu belirleyici olarak dini bilgiye yaklaşım, din öğretimini şekillendirici niteliktedir. Çünkü din öğretimi süreçlerindeki sınırlar, dini bilginin ne kadar ve nasıl yer alması gerektiğine ilişkin tutumlar, dini bilgiye yaklaşım ile şekillenmektedir.

Bilgi ve eğitim, sistemleşme süreçlerinde bir dünya görüşü üzerine temellendirilmeye muhtaç iki alandır. Din eğitiminin üzerine temellendirildiği dünya görüşü İslamî perspektifte iki düzeyde tanımlanabilir. İlki; bireyin dünya hayatı ve ontolojik sorgulamalarına karşılık gelen ve beşerî yorumu içeren dünya görüşü diğeri ise bireyin sahip olduğu değerler bütünüdür. Bunlardan ilki epistemolojik tartışmalara ikincisi ise ahlak temelli tartışmalara kapı aralamaktadır. ${ }^{13}$ Temelini bu noktadan alan bir din eğitiminin bireylere değer ve dünya görüşü kazandırmaya daha çok imkân verdiğini söylemek mümkündür. Nitekim Groom din eğitiminin ve din eğitimcisinin görevlerinden birinin, öğrencilere hayata dair dini bir bakış açısı ve yaratıcı inancı kazandırmak, olarak belirtmektedir. ${ }^{14}$ Ayrıca din eğitiminin amacı, bireylerde öğretilen din hakkında dini anlayış geliştirmektir. Bu durum öğrencilerin inançlarını geliştirmeye de katkı sunmaktadır. ${ }^{15} \mathrm{Bu}$ amaçların kazandırılmasında yalnızca sahip olunan eğitim yaklaşımı ve müfredat değil, din eğitimi öğretmenlerinin dini bilgi anlayışları da önemli bir yer tutmaktadır. Nitekim, dini bilgiye akademik bir durum veya olgu olarak yaklaşmak ile kutsal olarak yaklaşmak arasında farklılıklar bulunmaktadır.

Din öğretimi süreçlerinin sınırları hukukî, eğitim paradigması, öğretilen dinin bilgi sistematiği, öğretmenin yaklaşımı gibi pek çok etken ile sınırlanabilmektedir. Bunlardan en etkili ve denetimden uzak olanı ise din eğitimi öğretmenlerinin dini bilgi anlayışlarının genişliği ve derinliğidir. Öğretmenlerin dini bilgi anlayışlarını; değer yargıları ve inançları, pedagoji bilgileri, alan bilgileri, müfredat bilgileri, İslam alanyazını ve bireysel tutumları, bilgiye yaklaşımları, yönelimleri ve konunun bağlamı gibi pek çok unsur etkileyebilmektedir (Şekil 1). Bu anlamda öğretmenlerin dini bilgi anlayışlarını, bireylerin bilgiye ilişkin yaklaşımlarının bireyin eylemlerindeki içsel ve dışsal referans noktaları, bireysel deneyimi ile kazanmış olduğu tecrübeler, birden fazla kaynaktan beslenen kişisel bilgi anlayışı şeklinde ifade edilebilir. Çünkü bir olguya ilişkin geliştirilen anlayış ve algı ona ilişkin bilginin ötesinde yer almaktadır. Bu anlayış ve yaklaşımlar konu ve bağlama göre de değişkenlik göstermektedir. Dini bilgi anlayıșı din öğretimine ilişkin her şeyi veya herhangi bir şeyi ortaya koymaz. Ancak bireylerin inanç aşamasında uygulamaya geçmelerinden öncesi için bir fikir sunar. Bu bağlamda bir din içerisinde dini bilginin tek bir formu bulunmamaktadır. ${ }^{16}$ Din öğretimi süreçlerinde de bu farklı formların müfredattan çok eğitime öğretmenler üzerinden yansıdı̆̆ını söyle-

13 Wan Daud, İslam bilgi Anlayışı ve Çoğulcu Bir Toplumun Eğitim Sistemine Yansıması Malezya Örneği, 23.

14 Thomas H. Groome, What Makes Us Catholic Eight Gifts for Life (PDF: Harper Collins e-book, 2001), 193, 287.

15 Karen Walshe - Geoff Teece, “Understanding 'Religious Understanding' in Religious Education”, British Journal of Religious Education 35/3 (Eylül 2013), 313-325.

16 Walshe - Teece, “Understanding 'Religious Understanding' in Religious Education”, 313-325. 
mek mümkündür. Bu durum, din eğitimi öğretmenlerinin dini bilgi anlayışlarını benimsenen eğitim felsefesi, müfredat ve içerikten daha önemli bir konuma taşımaktadır.

\section{3. Öğretmenlerin Bilgi ve Dini Bilgi Anlayışları}

Tablo 1: Öğretmenlerin Dini Bilgiye Yaklaşımları Temasına Ait Kodlama İşlemi

\begin{tabular}{lll}
\hline Tema & Kategori & Kodlar \\
\hline \multirow{2}{*}{$\begin{array}{l}\text { Ögretmenlerin } \\
\text { Bilgi ve Dini } \\
\text { Bilgi Anlayışları }\end{array}$} & Bilgi Anlayışları & $\begin{array}{l}\text { Hayatın kendisi, davranışa dönüş̧ürme, Allah } \\
\text { vergisi }\end{array}$ \\
\cline { 2 - 3 } & $\begin{array}{l}\text { Bilgi ve Dini Bilgi Ay- } \\
\text { rımı }\end{array}$ & Ayrılamaz, farklıdır \\
& & \\
& &
\end{tabular}

\subsection{Bilgi Anlayışları}

$\mathrm{Bu}$ başlık altında "Sizce bilgi nedir? Bilgiyi nasıl tanımlarsınız? sorularına öğretmenlerin verdikleri cevapların kodlanmasıyla oluşmuş veriler ve yorumları yer almaktadır. Katılımcıların bilgiye ilişkin görüşlerinden; "hayatın kendisi”, "davranışa dönüştürme", "araç" ve "Allah vergisi” kodları elde edilmiştir (Tablo 1).

Hayatın Kendisi: Katılımcılardan K12, "uygulamadığın hiçbir şeyin anlamı yok. Bir kürek, balta tutmayı öğrenmiştir bu da bir bilgidir. Bilgi dediğimiz şey hayatın gerçekleri. Bilgi sadece oturup okumayla olmuyor." Bilgi yalnızca bilişsel düzlemde gelişen ve gerçekleşen bir olgu değildir. İnsanın günlük hayatta yaptığı bütün eylemleri bilgiye dayanmaktadır. K9, "Bilgi ulaşllması, öğrenilmesi gereken olgu. İşte bu olguların, ilkelerin tümünü elde etmeye biz bilgi diyoruz. Öğrenilmesi gereken, bilmediği her şey” diyerek, yaparak-yaşayarak öğrenmeyi kısacası bilgiyi kendisine bir hedef haline getirdiğini belirtmiştir. Görüldüğü üzere bilginin salt bilişsel boyutta zihindeki varlığı tam bir öğrenme olarak addedilmemektedir. Ayrıca K9 öğrenmede öznel yaklaşımı ön plana çıkarmaktadır. Neyi ne kadar öğreneceği bireye ve ihtiyaçlarına bağlı olarak gelişmektedir (K9).

Bilgi kavramı katılımcılar tarafından yalnızca eğitim-öğretim ve okul ile sınırlandırılmamıştır. Bilgi yaşamın kendisidir. Katılımcılar bilgi kelimesini hayat kelimesi ile eşleştirmişlerdir. K12, "İç içe yani hayatın kendisidir bilgi." Formel eğitimin yürütüldüğü alanı temsil eden okul ile informel eğitimin gerçekleştiği günlük hayat içindeki her şey bilgiye dâhildir. Katılımcılardan K12 "Mutfaktaki durumdan öğrencinin buradaki durumuna kadar hepsi bilgidir"; K8 ise "Kullanabileceğim şeyleri öğrenmem" ifadesiyle bilgi kavramına yaklaşımlarının hayatın tamamını kapsayacak şekilde bütüncül olduğunu vurgulamışlardır. Bilmenin yapmaya etkisini ön plana çıkaran katılımcıların pragmatist bir yaklaşımda oldukları söylenebilir. Çünkü pragmatist yaklaşımın tecrübeyi ön plana çıkarmasındaki en temel neden bilmek ile yapmak arasında kurulan güçlü bağdır. ${ }^{17}$ Katılımcılara yönlendirilen bilginin ne olduğuna ilişkin soru, doğ-

17 Ahmet Cevizci, Eğitim Felsefesi (İstanbul: Say yayınları, 2016), 124. 
rudan bilginin zihinsel süreçleri ile ilişkilendirilse de katılımcların bilgiyi tanımlamaları daha çok onun eylemsel yönü olan öğrenme kavramıyla eşleştirilerek ortaya konulmuştur. $\mathrm{Bu}$ anlamda din eğitimi öğretmenlerinin bilgi kavramını ele alışları bilginin türü fark etmeksizin öncelikle bilişsel boyutta, sonrasında ise bilgi-eylem ilişkisinde bilginin davranışa dönüşme boyutuyla değerlendirilmiştir (K12, K8, K9). Katılımcıların bu yaklaşımlarını bilgiye doğrudan bir tanımlama getiremedikleri için sağduyuya uygun açıklamalar ile ortaya koydukları söylenebilir.

Davranışa Dönüştürme: Katılımcıların bilgi tanımlamaları öğrenme ve öğretme eksenindedir. Bilgi kavramını öğretimin bilişsel, duyuşsal ve psikomotor alanlarından yola çıkarak değerlendirmişlerdir. K7, "Bilgi, öğrendiğinin hayata yansıması. Hamallık olarak değil eğer o bilgi hayata aksediyorsa bilgidir." K7, bilginin hayata aksetmeyişini Kur'an'a atıfta bulunarak eleştirmektedir. ${ }^{18}$ Bilginin hayata yansıması durumunda var olabileceği düşüncesi mevcuttur. Bunun geleneksel eğitimin bilgi anlayışı olduğu söylenebilir. Bilgiyi hayata aksettirmek olarak değerlendiren K18 de öğrenmenin psikomotor alana etkisine vurgu yapmıştır. "Bildiği ile amel etmedikten sonra bilgi çok da önemli değil." (K18). Katılımcilarda bilişsel boyuttaki bilginin önemsiz olduğu, ancak psikomotor alanda aktif hale gelmesinin bilgiyi önemli kılacağı anlayışı mevcuttur. "Bilgiyi veriyorum bazen bakıyorum ki çocuklar \%90 alyyor ama hiçbir karşllğı yok. Sadece bilgisayar dosyası gibi duruyor. Açmazsan yüz yll orada kalır. Sürekli işlenir halde olması için bilinç vermeye çalş̧ıyorum." (K13). Katılımcilar öğretim aşamasında bilginin bilişsel boyutunu değil, duyuşsal ve psikomotor alanlarda kullanılması boyutunu vurgulamışlardır. K13'e göre yalnızca bilişsel boyutta kalan öğrenmeler şuurdan yoksundur. Yine öğretme işinin psikomotor boyutuna atıfta bulunan K21 "insan her şeyi bilebilir ama yaşamıyorsa..." diyerek bilginin günlük hayatta kullanılması gerekliliğine vurgu yapmıştır. K21, K13, K18 ve K7 bilginin mutlak suretle davranışa dönüşmesi gerektiğini belirtmiştir.

Araç: Bazı katılımcılar $(\mathrm{K} 15, \mathrm{~K} 13)$ bilgi kavramını bir metafor üzerinden değerlendirmişlerdir. Bilgiyi su, ağaç, meyveye veya dünyadaki yaşam için yüksek düzeyde önem taşıyan bir nesne üzerinden somutlaştırarak zaman zaman da araçsallaştırarak ele almışlardır. Bilgiyi, insanı değişip dönüştüren bir olgu olarak gören K15 planya metaforu üzerinden bilginin işlevini açıklamıştır: "Marangozlar planya kullanır. Bilgi hayatıma şekil veren, beni bir kaliba sokan bir planya diyebiliriz. Bilgi beni yontan, bana şekil veren, beni istikamete götürmeye çalş̧an bir araç." K15 bilgiyi, davranış değişikliğine sebep olması yönüyle planya ve bilgi arasında benzeşim kurarak planya metaforu üzerinden betimlemiştir. K15 idealist bir temelde insanın bilgiyi değil, bilginin insanı oluşturduğu fikrini sunmuştur. Bu yaklaşım ekseninde bilginin nesnel bir olgu olarak öğrenciye öğretilmesi veya öğrencinin onu bilişsel yolla edinmesi ve sonrasında da hayatında aktif olarak kullanması beklentisi söz konusudur. Ağaç metaforu ile bilgi K16 tarafından "gelişmemiz, insanın meyvesi diyebiliriz. Ya da insanı bir ağaca benzetirsek ağacın sulanması diyebiliriz. Su verilmesidir. Yoksa çürür.” şeklinde tanımlanmıştır. K13 "suya benzetirim ışı̆̆a da benzetmem yani. Bilgi bilmediğin şeydir, bildikten sonra bilgi haline

18 Kur'an-ı Kerim ve Elmalılı Meâli, çev. Mustafa Özel (İzmir: Akit Yayınları, 2011), Cuma, 62/5. 
gelir. Su da sürekli yerin altında, karanlkta kaliyor, ortaya çlktıkça sen onu görüyorsun." Bu yaklaşımda da idealist felsefenin ${ }^{19}$ etkilerini görmek mümkündür. Zira bilginin insanın varlığından bağımsız olarak varlık gösterdiği ve bu bilginin insan tarafından yalnızca keşfedildiği düşüncesi mevcuttur. Ancak bilgi olarak adlandırılması için insan zihnindeki bilişsel sürece ihtiyaç duymaktadır. Bununla birlikte bu yaklaşımı üst düzey düşünme becerilerini sınırlandıran metafiziksel bir yaklaşım ile de açıklamak mümkündür. Çünkü dini bilgide salt metafiziksel yaklaşım geleneksel ve ideal tutumundan dolayı kendi içinde kapalı bir hal alarak bilginin gelişiminde insan tecrübesini dışlayabilmektedir. ${ }^{20}$

Katılımcıların bilgiyi araçsallaştırmaları durumu söz konusudur. Bilginin bir araç olarak görülmesi bilginin işlevselliği tartışmasını da ortaya çıkarmaktadır. Bu anlamda katılımcılardan bir kısmı bilginin insan hayatını değiştirip dönüştüren yönüyle değerlendirmekte ve ne derece değişime sebep oluyorsa o derece işlevsel olduğunu düşünmektedirler. Bu minvalde katılımcılarda bilginin varlığının değişim ve dönüşüme kesin olarak katkı sunduğu inancı bulunmaktadır. "Bilgi, insanın hayatın kolaylaştırmak, çözüm üretebilmek için ele aldığı değer. Toplumun inançları ve değerleri var. Hayatın akışı hep ileriye doğru gidiyor, geri dönmüyor. 0 birikimi kendisine alıp geleceği daha kolaylaştırma, hayatına rahat, düzgün yollar çizmek, kolaylaştırmak için dayandiğı dayanak noktası." K14, ilerlemeci bir anlayış ile bilginin sürekli bir ilerleme içerisinde olduğunu düşünmektedir. Öğrencilerin de bu sürekli ilerleyiş içerisinde bilginin kendi hayatlarını kolaylaştırıcı yönlerini yakalayarak bilgiyi kazanılabileceklerini belirtmiştir. Bu değerlendirme, kültür temelli bir yaklaşım izlenimi verse de burada bireylerin var oldukları toplum içerisinde öznel öğrenme ile edindikleri bilgi tecrübeleri ekseninde bir anlayış vardır. Bu bilginin ise bireyin hayatı paralelinde işe yarar nitelikte olması beklenmektedir. Bilgi, bireyin bilişsel süreçleri ve epistemoloji açısından bireysel eylem kuram ilişkisi olan aksiyoloji yönüyle toplumsal bir boyut kazanmaktadır. $\mathrm{Bu}$ haliyle bilgiye değerler, ahlak ve düzen boyutlarında işlevsellik kazandırılmaktadır. Bilgi, sadece insanı değiştirip dönüştüren bir araç olmayıp insan hayatını kolaylaştırmaya da vesile olmaktadır. K11, "Kişinin bütün hayatın hem akademik hem madden hem de manen devam ettirebilmesi için gerekli bir şey. Dini olarak bizim bu dünyadaki varoluş amacımıza hizmet edebilmek için bilgiye sahip olmamız gerekiyor... Bilmeden hiçbir şey yapamayız... İhtiyaçtır." Buna göre bilgi hedefe ulaştırmada araçtır.

Allah Vergisi: Bilgi olgusu ile din, katılımcilar tarafından zaman zaman doğrudan bağlantılı bir şekilde değerlendirilmiştir. ìlk bilenin ve ilk bilginin Allah'ın varlığı ile açıklanması bu tarz bir yaklaşım sunmaktadır. Katılımcılardan K10, K5 ve K1 bilgi tanımlamalarını bilginin kaynakları itibariyle ele almıştır. Bilgiye ilahi bir sıfat yükleyerek Allah tarafından gönderilmiş olduğuna işaret etmişlerdir. K10 "Allahutaala insana ne diyor 'kalem ile yazmasını öğretti' bu bilgi üzerine oluşturulmuş bir şey. Bilginin sınır yok ama bizim için bilgi, bazı şeylerin sınırı var..." şeklinde ifade etmiş̧ir. Benzer

19 Gerald Lee Gutek, Eğitimde Felsefi ve İdeolojik Yaklaşımlar (Ankara: Ütopya Yayınevi, 2019), 23-24.

20 John Hick, Faith and Knowledge (Hong Kong: The Macmillan Press, 1967), 203. 
olarak K1 de "gerçeğin en şeffaf hali olarak tasavvur edebiliriz bilgiyi. Bilgi varoluşun ta kendisi. Bu da tanrının yarattı̆̆ı var ettiği bir şey. Allah alimdir.” K10 ve K1 bilgiyi daha çok maneviyatçı ve aşkın bir yaklaşım ile ele almışlardır. Bilgi yaratıcı kaynaklı olup insan sahip olduğu yetenekler ile yalnızca ona katkı sunabilmektedir. Bilgiye böyle bir yaklaşım bilginin ancak nakline imkân vererek öğretimini sağlamaktadır. Burada bilgiye metafiziksel bir anlam yüklenmiş ve ilahi kaynaklı olduğu için bilme eyleminde bir sınır ortaya çıkmıştır. K1 ve K10'a yakın bir düşünce sunan K5 de "Bilgi, Allahutaala ilim sıfatının insanlara yansımasıdır." Şeklinde bilgiyi tanımlamıştır. Katılımcıların tevhid ekseninde ortaya koymuş oldukları bilgiye bu yaklaşımları İslam düşünce geleneğinde Ehl-i sünnet görüşleri paralelindedir. ${ }^{21} \mathrm{Bu}$ bakış açısıyla K1, K5 ve K10'un bilgiyi bütüncül olarak ele alıp dini veya dini olmayan şeklinde bir ayrıma tabi tutmadıkları söylenebilir. Ayrıca K1, K5 ve K10 bilginin kaynağını idealist ve spiritüalist felsefelerde olduğu gibi yaratıcıya dayandırmışlardır. İnsan tecrübesinden bağımsız bir değerlendirme ile bilginin ancak yaratıcı tarafından insana verilebileceği ortaya konulmuştur. Katılımcılar bilginin kaynağını dini bilgi kaynağı ile eş değer görmektedirler. Bundan dolayı bilgiyi de dini bilgi olarak tanımlamaları söz konusudur.

Katılımcılar yöneltilen sorulara öğretmen kimliği ve rolleri ile cevap vermişlerdir. Bu bağlamda bilginin tanımlanmasından ziyade katılımcılar bilgi ve dini bilgiyi, öğretme ve öğrenme süreçlerinde ortaya çıkması beklenilen sonuçları üzerinden değerlendirmişlerdir. Katılımcılardan K7, K13, K15, K21 ve K18 bilginin eyleme dönüşmesinin bilginin ayrılmaz parçası olarak belirtmiştir. Öğretmenlik mesleğinin kazandırmış olduğu bakış açısı ile bilgiye öğrenen açısından yaklaşmışlardır. Katılımcılar bilgi-davranış ilişkisi bağlamında bilgiyi aksiyoloji açısından ele almışlardır. Bu yaklaşımın altında bilginin davranışa dönüştürülmesi beklentisi yer almaktadır. Bu durum, bilgi-eylem arasında zorunlu bir ilişki kurulması olarak değerlendirilebilir. Öğretmenlerdeki bu beklentinin eğitimin özünde olan 'istendik davranış değişikliği' geliştirme hedefi doğrultusunda ortaya çıktığı söylenebilir. Katılımcıların bilgiye epistemolojik açıdan spiritüalist ve idealist yaklaşımları varken aksiyoloji açısından pragmatist, idealist yaklaşımları bulunmaktadır. Bundan dolayı katılımcıların bilgi kavramını felsefi bir temelde değil dini bir temelde değerlendirdikleri söylenebilir. Zira bilginin dini bilgiden bütünüyle bağımsız olarak değerlendirilmesi söz konusu olmamış katılımcıların bir kısmı (K1, K5, K10) bilgi anlayışlarını din referansı ile ortaya koymuştur. Bilgi kavramı katılımcılar tarafından bütüncül bir yaklaşım ile ele alınarak spiritüalist bir anlayışla, bilgi de dâhil varlık alanında yer alan her şeyin Allah tarafından insana verildiği düşüncesiyle açıklanmıştır. Katılımcıların dini bilgi anlayışlarında inançları temelinde anlam dünyaları ile çevrili bir anlayışın varlığından bahsedilebilir.

Öğretmenlerin uzmanlık alan bilgileri ile bilgiye yaklaşımları ilişkilidir. Öğretmenlerin alanlarına ilişkin bilgilerine yaklaşımları ve öğretim yollarını benimseme-

${ }^{21}$ Alparslan Açıkgenç, “İslam Bilgi Nazariyesi”, İslam’a Giriş, ed. Bünyamin Erul (Ankara: Diyanet İşleri Başkanlığı Yayınları, 2007), 11-30. 
lerinde genel olarak bilgi anlayışlarının da etkisi bulunmaktadır. Araştırmada bu bağlamda yapılan araştırmaları destekleyici verilere ulaşılmıştır ${ }^{22}$ (Şekil 1).

Şekil 1: Din Eğitimi Öğretmenlerinin Bilgi ve Dini Bilgi Anlayışlarının Temeli

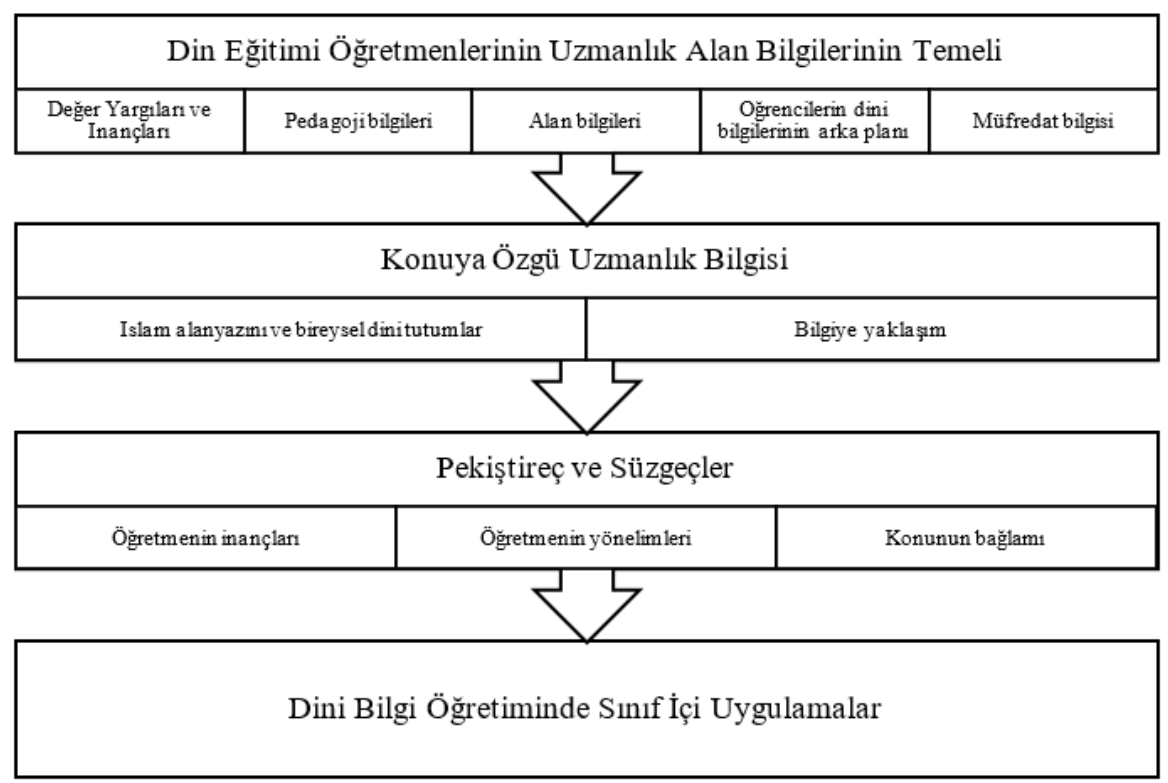

\section{2. Öğretmenlerin Bilgi ve Dini Bilgi Ayrımı}

Katılımcılar bilgi kavramını farklı nitelikteki bilgiler ile eşleştirmişlerdir. Bilgi kavramı zaman zaman bilimsel bilgi olarak bazen de günlük bilgi şeklinde kullanılmıştır. Dini bilgi ve bilgi arasındaki ilişki, katılımcılar tarafından dini bilginin temellendirilmesi ve dini bilginin kaynağı itibariyle iki biçimde değerlendirilmiştir. Kat1lımcı görüşlerinin analizinde, onların dini bilginin neliğine ilişkin görüşlerine dair yapılan kodlamalar sonucunda bazı görüşlerin "bilgi” ve "dini bilgi ayrımı" kategorisi altında toplanabileceği tespit edilmiştir. Bunlar; ayrılamaz ve farklıdır şeklinde iki koddan müteşekkildir.

Ayrllamaz: Yapılan analizlerde bazı katılımcıların bilgi ve dini bilgi arasında ayrım yapmadıkları hatta bilgiyi bir bütün olarak değerlendirdikleri tespit edilmiştir. K7 “iç içe geçmiş olarak görüyorum, ayıramayız. Etle kemik gibi birbiri içine geçmiştir. Mesela bir coğrafyadan, tarihten, sosyolojiden, matematikten din eğitimini ayıramazsınız. Öğrencilere diyorum dini ilimlerle diğer ilimler bir bütün, bir kuşun çift kanadı..." cümleleri ile dini bilgi ve diğer bilgilerin ayrılamayacağını ifade etmiş ve her ikisinin birbirini desteklediği belirtmiştir. K7 bilgi ve dini bilgiyi ayıramayacă̆ını belirtmekle birlikte bu bilgilere ilişkin tam bir ayrımdan öte birbirini destekleyen iki bilgi türünden bahsetmiştir. K7 dini bilgiyi din eğitimi ile eşleştirerek değerlendirmiştir. Buna göre eğitimde yer alan

\footnotetext{
22 Julie Gess-Newsome vd., “Teacher Pedagogical Content Knowledge, Practice, and Student Achieve-
} ment", International Journal of Science Education 41/7 (May1s 2019), 944-963. 
dini bilgi ve diğer branşların bilgileri birbirini tamamlayıcı niteliktedir. Her birinin varlığı bir diğerinin anlaşılmasını kolaylaştırmaktadır. Dahası K7 her iki bilgiye de sahip olmadan yalnızca biri üzerine temellendirilen eylemler ve düşünsel yapılarda mutlaka bir eksiklik bulunacağını belirtmiştir. K7'ye paralel olarak K1 dini bilgi ve bilgiyi holistik bir bakış açısıyla İslam referansında "ilm" kavramı ile değerlendirmektedir. Bu bilgilerin birbirini nasıl tamamladıklarını $\mathrm{K} 1$ şöyle açıklamıştır; "Allah’n kitabı ile Allah’n koyduğu tabiat kanunlarının birbiri ile çelișmesi olamaz. Ancak birbirlerini tamamlayıcı bir fonksiyon içerebilirler. Ama elbette nüans açısından bir farktan bahsedebiliriz. Dini bilgi biraz daha normatif, norm içeriyor kural içeriyor... dini bilgi seni biçimlendiriyor, sınırlandırıyor, değiştiriyor." Buna göre dini bilgi ve diğer bilgiler çelişmemekte ve birbirini tamamlayıcı ve bütünleyici niteliktedir. K1'e göre dini bilgi insanları kendi sistematiğinde barındırdığı norm ve ilkeler ile değiştirip şekillendirirken diğer bilgiler hakikati tanımlamada yardımcı olmaktadır. Görüldüğü gibi dini bilgi ve diğer bilgiler arasındaki ilişki kuram-eylem ilişkisi bağlamında ele alınmıştır. K7'ye göre yaşamı yalnızca dini bilgi veya dini olmayan bilgiler üzerinden sürdürmek mümkün değildir. Benzer bir yaklaşım ile K1 de dini bilgi ve diğer bilgilerin birbirini tamamladıklarını belirtmiştir. Çünkü en nihayetinde bilgi de dini bilgi gibi Allah tarafından insana verilmiştir. Katılımcılara göre bundan dolayı bilgi ve dini bilginin ayrılması ve çelişmesi söz konusu olamaz. Bu bağlamda eğitim içerisinde sunulan bütün dersler birbirini tamamlayıcıdır. Ayrıca K1 dini bilginin kullanmış olduğu üslup ve dil bakımından diğer bilgilerden ayrıldığını çünkü dini bilginin özünde ilahi kaynakla gelen bir normlar bütünü olduğunu düşüncesini savunmuştur. K1'e göre insanı ve hayatı şekillendirme hedefi dini bilginin buyurgan bir dil kullanmasını olağan kılmaktadır.

K15 ve K13 dini bilginin "ayrlmaz çünkü her bilginin öyle veya böyle hakikate kiyısından kössesinden de olsa dokunabileceğine inanıyorum. Astronomi okuyan, fizikle ilgilenen bir kişinin de... yeter ki bilgiyi sağlam bir kaynaktan alsın, hakikate götürebileceğini düşünüyorum. íkisinin birbirini tamamladığını düşünüyorum..." sözleriyle dini bilgi ile bir şekilde kesiştiğini ve bir bütünlük oluşturduğunu düşünmektedirler. K15 bilgi kavramını hakikat kavramı ile eşleștirmiştir. Böylelikle kaynağı doğru olan her bilgi insanı hakikat olan dini bilgiye götürmektedir. Bu anlamda K15'e göre insan astronomi, fizik ilmi ile uğraşsa bile doğru bir mantık düzleminde ise bu bilgi onu hakikate ulaştırma potansiyelindedir. Böylelikle bütün bilgiler bir bütünün ve hakikatin parçası haline gelmektedir. K13 "Bilgi bilgidir hepsi aynıdır. Dini bilgi de bilgidir diğer bilgiler de... Bütün bilgileri Allah'in gönderdiğine inanıyoruz o yüzden birbirinden kesinlikle ayrlamaz. Bir çocuk fen dersini öğrenirken aynı zamanda Allah’ı öğreniyordur..." K13 de K15’e benzer bir şekilde bütün bilgilerin hedefinin insanı hakikate götürmek olduğunu belirtmiştir. Ancak K15, K13'ün bu ifadelerine ek olarak bilginin hakikate ulaştırmada en önemli ölçütü bilginin sağlam bir kaynaktan alınması koşulunu ifade etmiştir. K15, sağlam ifadesini doğru ifadesi ile eşleştirerek kullanmıştır. Katılımcılardaki bilgi ve dini bilgiye ilişkin bu holistik yaklaşımın Kur'an ile temellendirildiği söylenebilir. Bu bağlamda katılım- 
cıların bilgi kavramına yaklaşımlarının İslam düşünce geleneğinde yer alan bilgi anlayışı paralelinde olduğunu söylemek mümkündür. ${ }^{23}$

“İslam'da dini bilgi diye bir şey yok, bütün bilgiler eğer seni Allah'a ulaşttriyorsa...Ister matematik ister fizik, kimya, biyoloji, din fark etmez. İslam'in öğretisinde bilimsel bilgi, dini bilgi diye bir ayrım yok. Sonradan ayırt edilmiş bilgiler... her șey Allah'tan bahsettiği için dini, İslami bir değer taşıyabilir." diyen K14 için diğer bilgileri öğrenmek dini bilginin öğrettiği Allah mefhumunu pekiştirici niteliktedir. K14'e göre bilgi ve dini bilgi ayrımı İslam eğitim geleneğinde bulunmamaktadır. K14 de K13'e benzer olarak bütün bilgiler zaten Allah'ı anlatmaktadır görüşündedir. K5, "ayırmak mümkün değil. Hayatın içindeki her şey zaten dinle alakalıdır. Ama dini olmayan, teknik bilgiler ayrrm yapabiliriz. Yani teknoloji ile ilgili bilgiler dinin dışında belki olabilir. Ama temel hedefleri yine dinle alakal." ifadesi ile K13, K15 ve K14'e benzer olarak bilginin bütünlüğünü vurgulamaktadır. Çünkü zaten bütün bilgiler Allah'ı anlatmakta ve O'na götürmektedir. Böylelikle bütün bilgiler dini bilgi ile iç içedir ve birbirini tamamlayıcıdır. Ayrıca K5 teknik bilgileri din ile ilintili bulmakla birlikte bunların dini bir bilgi muhteva etmediklerini belirtmektedir. Ancak bunlar bireyleri dini bilgiye ulaştırmaya vesiledir ve bir yönüyle hepsi dini bilgide buluşmaktadır. K5'e göre dini bilginin sosyal hayatın bütün alanlarına sirayet ederek hayatın her alanında görülen bir bilgi türüdür. Burada işlevselci bir yaklaşım ile bilginin uygulama alanı ve işlevi birbirinden ayrılan yönü vurgulanmıştır. Katılımcılar bilgi ve dini bilgiye bütüncül yaklaşmış ancak bilginin işlevi noktasında bilgiyi ayırmışlardır.

K21 "Allah inancını anlatırken, evrendeki düzeni... Fen Bilgisi laboratuvarını, ayetlerle dünyadaki düzeni, gezegenleri anlatan bir sürü şeyler vardı. Yaptı çocuklarla kartonlara laboratuvara astık. Fen dersinde de çocuk o konuyu işlerken gösterdiğim ayeti görsün, gözüne çarpsin. Amacım çocukların zihinlerinde dersleri birbiriyle, disiplinler arası ilişki kurup inancı sağlam temele oturtmaların sağlamak."

K21'e göre dini bilgi en temel bilgidir. Diğer bilgiler dini bilginin etrafında şekillendirilip ona göre anlatılabilir. K21 aslında dini bilgi ile diğer bilgiler arasında bir ayrımın olmadığını ifade etmiştir. Ancak branş olarak dersler arasında bir ayrım söz konusudur. K21 yukarıda belirtilen görüşlere benzer olarak dini bilginin diğer bilgi türleri ile bir bütün olarak anlaşıllp öğrenilebileceğini belirtmiştir. Buna göre branşlar arasındaki farklılık, bilgi türleri arasında kırmızı çizgiler ile kesin bir ayrımı getirmemelidir. K21, bilgiye yönelik bütüncül bir yaklaşım ifade etmekle birlikte dini bilginin öğretimi sürecinde öğretmenlerin dini bilgiyi diğer branşlardaki bilgiler ile destekleyerek rasyonelleştirme ve somutlaştırma ihtiyacını ortaya koymuştur.

K18, "Fen Bilgisi öğretmeni dini değerlerden bahsetse belki Din Kültürü öğretmenine göre daha faydalı olur" ve K16'nın "Din Kültürü öğretmenlerinin sadece din bilmedikleri başka şeyler de bilmeleri çocukların hoşlarına gidiyor." ifadeleriyle din eğitimi öğretmenin imajına yönelik bakış açısı diğer branş öğretmenleri ile mukayese edilerek dini bilginin öğrenciye farklı branşlardaki öğretmenler tarafından verilişinin daha etkili olabi-

${ }^{23}$ Açıkgenç, İslâm Medeniyetinde Bilgi ve Bilim, 38-50. 
leceği kanaati ortaya konulmuştur. Bunun sebebi ise "Çünkü o fencidir ondan fen beklerler. Ara sıra dini mevzulardan bahsetmesi de ilgi çekici gelir.” (K18) şeklinde açıklanmıştır. K18’in bu yaklaşımından katılımcıların din eğitimini tek bir ders ile sınırlı görmedikleri, bütün bir müfredatın din eğitimine katkı sunması gerektiği beklentilerinin olduğu çıkarılabilir. Din eğitimi öğretmeninin imaj1 dini bilginin öğretiminde öğrenciler açısından bir etken olarak dile getirilmiştir. Katılımcıların dini bilginin fen bilgisi veya diğer branş öğretmenleri tarafından öğretilmesini beklemeleri, dini bilginin öğretiminin aslında bir pedagojik yönteme ihtiyaç duyulmadan gerçekleşebileceği düşüncesine dayanabilir. Bu durum dini bilginin bir müfredata ihtiyaç duyulmadan sistemli bir eğitimin dışında da öğretilebileceği düşüncesini ortaya çıkarabilir. Dini bilginin öğretimi aslında bir eğitim konusu değil yaşamsal döngüde bir referans noktası olarak sunulan bir bilgi olarak görülmektedir. Bu bakış açısı dini bilginin öğretilen olmaktan ziyade yaşanan bir olgu olmasına vurgu yapmaktadır. Bu anlamda dini bilgi bütün bilgileri kapsayıcı niteliktedir. Ancak diğer bilgilerin böyle bir durumu söz konusu değildir. Dini bilgi ve diğer bilgiler nihai noktada ilahi kaynağa dayalıdır. Bilgilerin birbirinden ayrılamadığı nokta da burasıdır. Bu yaklaşımda din eğitimi öğretmenlerinin dini bilgi öğretiminde manevi bir eksende sürdürülmesi gerektiğine yönelik bir inanış söz konusudur.

Farklıdır: Katılımcıların dini bilgi kavramını bilgi kavramından ayıran görüşleri de mevcuttur. Bu durumu K18, "Bilgi ile dini bilgi farkh şeyler elbette! öğrenciye matematik dersinde üçgen çizip de iç açılarının toplamı hipotenüsü, trigonometriyi anlatmak gibi bir şey değil. O bilgi ile bu bilgi farkl. Bunun içerisine biraz akıldan ziyade inancın girmesi gerekli" ifadeleriyle ortaya koymuştur. Dini bilgi, K18 tarafından inanç-bilgi ilişkisi boyutuyla diğer bilgi türlerinden ayrılmıştır. Böylelikle dini bilgi inanç ile temellendirilmesinden dolayı epistemolojinin değil inancın konusu olmaktadır. K18 inanç ve doğrulanmış inanç olan bilgiyi yöntemsel açıdan ayırmıştır. Her bilginin önermesel bir inancı olması onun bilgiye dönüşümünden önceki hali ile bilgiden ayırmaktadır. Burada inancın evrildiği nokta ile ilgili bir yöntem ortaya çıkmaktadır. ${ }^{24} \mathrm{~K} 18$ 'in dini bilgiyi diğer bilgi türlerinden ayırdığı nokta da burasıdır. K18'e göre diğer bilgi türlerinde kısmen farklı yöntem ve yaklaşımlar ile somutlaştırılma imkânı oluşurken dini bilgi daha soyut bir düzlemde inancın imana dönüşmesi ile ilerlemektedir. K18'in ifadelerinden yola çıkarak bu durumun dini bilgiyi diğer bilgi türlerinde olduğu gibi somut ve gözlemlenebilir bir olgu olmaktan çok kişisel deneyimle beslenir hale getirebilme potansiyeline sahiptir.

Dini bilgiyi diğer bilgi türlerinden mutlak olarak ayrı gören K12 ve K19 "mutlaka dini bilgi farklıdır.", "bir farklllı arz eder tabii ki" ifadeleriyle dini bilgiyi diğer bilgi türlerinden kesin bir şekilde ayırmaktadır. K10 ise bu ayrımın temellerini Gazali'ye dayandırmaktadır. "Gazali de ayırıyor mesela. Ben de ayırıyorum, sonuçta sinırları var. Ama mesela edebiyatta öyle değil, tarihte de bir şey katarsın. Din alanı olduğu için yorum yapmaktan kaçınıyoruz, korkuyoruz, dışlanıyoruz. Zor bir alan rivayet oluşu... Ama kimyacı, fizikçi

24 Ferit Uslu, Felsefi Açıdan İmanı Temellendirme (Ankara: Ankara Okulu Yayınları, 2004), 26. 
olsam alemi kendi alanım üzerinden daha güzel yorumlayabilirim" K10 dini bilginin rivayet kültürüne dayalı bir birikime sahip olduğu için bireysel yorumlar ile katkı sunmanın zorluğuna dikkat çekmiştir. Hatta ona göre bu yorum ve katkılar zaman zaman fikir ayrılıkları temelinde dışlanmalara neden olmaktadır. Dini bilgi diğer bilgi türlerinden bu yönüyle ayrılmaktadır. K10'a göre dini bilgide yorum subjektif olarak algılanırken diğer bilgi türlerinde yorum, dini bilginin pekişmesi için yardımcı bir unsur konumuna gelebilmektedir. Bu yaklaşım dini bilginin mutlak ve dogmatik yönünü vurgulamıştır.

K16 dini bilgiyi diğer bilgi türlerinden kaynakları ve sabiteleri yönüyle mutlak olarak ayırmaktadır. "Tabi dini bilgi faklıdır bilimsel bilgiden kaynakları itibariyle, bilimsel bilgi değissebilir ama dini bilginin değişemeyeceğini düşünüyorum." Dini bilginin değişmezliği onun dogmatik yönüne vurguyu getirmektedir. Kaynağı itibariyle ilahi olan bir bilginin değişme şansı yoktur. Bununla birlikte dini bilgi için "Mefhum olarak aynı ama içerik olarak farklıdır. Dini bilginin kaynağı vahiydir değil mi? Bir de havas-ı selime dediğimiz işte düşünme, beş duyu organı. Bu beş duyu organı bir akılda birleştiği zaman ne oluyor? Dini bilgi elde edebiliyorduk ...Diğer bilgi, pozitif bilgi diyelim o daha farkl, nedir? İște tekniktir, bilimdir, teknolojidir, fendir. Onlar biraz daha farkl..." diyen K9 bilginin bir olgu olarak dini bilgi ile aynı nitelikte olduğunu belirtmiştir. K9'a göre varlık alanındaki tuttuğu yer ve temsiliyeti insandan bağımsızdır. Bilgi ve dini bilgiye bir olgu olarak yaklaşım onu yalnızca anlamayı ve öğrenmeyi getirmektedir. K9'un bu bilgi anlayışını düalist temelde idealizm ile açıklamak mümkündür. Öğretmene düşen tek görev ise bireyin dışında varlık gösteren bu bilgiyi öğrenciye fark ettirmek ve varlığından öğrenciyi haberdar etmektir. K9, bir olgu olarak bilgi ve dini bilgi varlık sahasında ortak alanı paylaşsalar da kaynakları itibariyle birbirinden ayrıldıklarını ifade etmiştir. Dini bilginin ana kaynağı vahiy olmakla beraber beş duyu organı ve akıl onu destekleyici niteliktedir. Bu noktada K9 dini bilgiyi pozitif bilimler ve manevi bilimler temelinde ayırmaktadır. Ona göre manevi bilimlerin kaynağı vahiy iken pozitif bilimlerin kaynağını yalnızca duyular ve tecrübe ile sınırlandırmak mümkündür.

K20, "normal bilgi de yine insanin aklı ve mantiğryla elde ettiği șeylerdir." K20'ye göre bilgi insan faktöründen bağımsız değildir. Bilgiye ulaşmada insanın yetenek ve gayreti önemlidir. Bu yaklaşımda bilgi ancak insan ile var olan bir olgu olarak karşımıza çıkmaktadır. Bilginin tarihsel gelişimine bakıldığında bilginin neliği konusunda bazı katılımcılar bilgiyi dini bilgi ile özdeşleştirmiştir. Ancak K20 bilgiyi normal ve dini olarak ayırmıştır. K8, "Diğer bilgiler o kadar da zorunlu değil...Kaynakları itibariyle kesinlikle ilahi kaynaklı olması...Ama diğer bilgiler beşerî kaynaklı olduğu için bu anlamda ayrilır." ifadeleri ile bilginin dini bilgiden ayrıldığı temel noktayı, dini bilginin ilahi kaynaktan beslenmesi diğer bilgi türlerinin ise beşerî kaynaklar ile gelişip çoğalması olarak belirtmiştir. Ayrıca K8 dini bilginin diğer bilgilerden ayrıldığı noktayı öğrenmenin farz olduğu ve dini bilginin günlük hayata yansıtılarak kullanılması gerektiğini de eklemiştir. Bu yönüyle K8'e göre dini bilgi kendisine inanan bireyler için yaptırım gücüne sahiptir. 
K2, “dini bilgi vahiy kaynaklı çoğunlukla...Tabi kaynakları itibariyle ve kalbi bir şey de gerektiriyor... Isşittik ve itaat ettik dediğimiz anda dini bilgiyi diğer bilgilerden, kaynakların hepsinden ayırmış oluyoruz zaten. Dini bilgi, her ne kadar eleştirel yaklaşsam, sorgulasam, akletsem, felsefi bir bakış açısı geliştirsem de neticede 'isittim ve itaat ettim' o yüzden ayırıyorum" ifadeleri ile diğer katılımcılar gibi bilgiyi kaynakları itibariyle ayırmıştır. Ancak diğer katılımcılardan farklı olarak K2 dini bilgiyi diğer bilgi türleri veya akıl ile değil kalp ile desteklemek gerektiğini de ifade etmiştir. Bu anlamda K2, K18'e benzer olarak dini bilgide inanç boyutunu vurgulamıştır. Buna göre dini bilgi büyük ölçüde inançtır ve vahiy aracılığıyla gelen bilgilere iman etmektir. K2 dini bilgileri yalnızca akıl ve tecrübe ile açıklamanın zaman zaman imkân dışı olduğunu bu noktada ise yine Kur'an'da da belirtildiği gibi sadece iman edilebileceğini belirtmiştir. K2 dini bilgiye bu yönüyle diğer bilgilerden farklı olarak dogmatik ve spiritüalist bir özellik atfetmektedir. İnsanın sahip olduğu yetiler bu bilginin doğruluğunu veya yanlışlığını ortaya çıkarabilecek düzeyde değildir. Dini bilgi her ne kadar sorgulanabilir ve eleştirilebilir bir yaklaşım ile ele alınabilse de bunu yapmak oldukça sınırlıdır. Bu sınır, dini bilgiyi bir noktada yalnızca iman edilebilir bir aşamaya getirmektedir. Bir inancın sürdürülmesi ve varlığı için her zaman aklî delillendirmeler yapmak mümkün olmayabilir. Bu noktada insan sezgiye yönelir ve zaman zaman tikellik baskın olabilir. Sezgi aynı zamanda bilginin mistik kaynağı olarak da düşünülür. Sezginin oluşmasında insanların tecrübeleri büyük önem taşır. Örneğin bilinçli veya bilinçsiz gözlemlerimiz sezgisel tutumlarımızda kaynak veya yönlendirici bir unsur olabilir. Yine aklî temellendirmelerin az olduğu konularda da sezginin daha baskın olduğunu söylemek mümkündür. ${ }^{25}$ Dini bilginin spiritüalist ve dogmatik yönünün burada belirginleştiği söylenebilir.

Katılımcılar diğer bilgi türlerini bilimsel bilgi, teknik bilgi, matematik, fizik, kimya bilgisi gibi bilgiler ile eşleştirmiştir. Bu anlamda katılımcılar dini bilgiden ayırt edilebilecek bir bilgi olarak doğrudan bilimsel bilgiyi anlamaktadır. Katılımcılardan yalnızca K2, K1, K16, K10, K12, K19 ve K18 bilgi ve dini bilgiyi kaynakları açısından ayırmaktadır. Katılımcıların büyük çoğunluğu (K1, K5, K7, K13, K14, K15, K21, K5, K8, K18) bilgiyi bütüncül bir yaklaşım ile ele almış ve ilahi kaynağa dayandırmışlardır. Dini bilgiyi, bilgiden ayıran katılımcılar bu ayrımı daha çok kaynaklarından yola çıkarak yapmaktadırlar. Ayrıca dini bilgi ve bilgi ayrımında, dini bilgiye daha çok ihtiyaç duyulduğu için ve öğrenilmesinin zorunluluk taşıması sebebiyle diğer bilgilerden ayrılabileceği söylenebilir. Bilgi ve dini bilgi insandan bağımsız gören katılımcrlar da mevcuttur.

Katılımcılardan K21, K9, K18 ve K4 dini bilginin soyutluğuna vurgu yapmışlardır. Din eğitimi öğretmenlerinin, dini bilgiye ilişkin bilgi ve dini bilgi arasında farklılık olup olmadığını ortaya koyabilecek düzeyde bilgi ve fikir sahibi oldukları sonucu çıkarılabilir. Katılımcılara göre dini bilgiyi diğer bilgilerden ayıran en temel unsur vahiydir. Bilgi, dini bilgiyi tamamlayıcı nitelikte olmalıdır. Katılımcılara göre bilginin

25 W. V. Quine - J. S. Ullian, Bilgi Ağı, çev. A. Hadi Adanalı (Ankara: Kitabiyat Yayınları, 2001), 82. 
dini bilgi ile diğer bilgiler arasında hayatı anlamlandırmaya dair derin bir ilişki ve bütünlüğü bulunmaktadır. Bu bakış açısını dini bilginin işlevi üzerinden de okumak mümkündür.

\section{3. Öğretmenlerin Dini Bilgi Kaynakları}

Din eğitimi öğretmenlerinin dini bilgi kaynaklarındaki tercihleri, dini bilgiyi nasıl anladıkları noktasında belirgin ipuçları sunmaktadır. Din eğitimi öğretmenlerinin dini bilgi kaynakları kategorisindeki analizlerde "Sizce dini bilginin kaynağı nedir?, Dini bilginin öğretiminde siz hangi kaynakları kullanırsınız?” sorularına verilen cevaplardan elde edilen verilerden yararlanılmıştır. Katılımcılar bu sorulara büyük ölçüde "Kur'an-1 Kerim, sünnet, sosyal medya, dini yayınlar” şeklinde cevaplar vermişlerdir. Bu ifadelerden yola çıkılarak ana kaynaklar ve ikincil kaynaklar kodları oluşturulmuştur.

Ana Kaynaklar: Katılımcıların büyük çoğunluğu dini bilgi kaynağı olarak Kur'an'1 belirtmişlerdir. Dini bilginin temellendirmesini Kur'an ve sünnet ile yapan katılımc1lar bu yaklaşımı İslam dini için bir zorunluluk olarak görmektedir. K6 "kaynak belli zaten Kur'an ve sünnet." Diyerek tercih ettiği kaynağını belirtmiştir. Katılımcılardan K3 dini bilgide kaynak olarak yalnızca Kur'an'1 görmektedir. “Temel kaynağım Kur'an'dır. Kur'an'a aykırı düşmüyorsa sünnettir. Telefonumda iki üç tane tefsir vardır, meal vardır bunları açarım. Diyanet mealini ve tefsirini temel kabul ederim her zaman." (K3). İslam düşünce tarihinde en önemli bilgi kaynaklarından biri olarak zikredilen ve dinin sistematik hale gelişinde büyük etkisi olan sünnet, katılımcılar tarafından temel bir kaynak olarak görülmekle birlikte K3’e göre Kur'an ile çeliştiği takdirde başvurulan bir kaynak olmaktan ç1kmaktadır. Benzer bir görüşü K2 "benim için bilginin kaynağı akıl ve vahiy. Başka bir kaynak tatmin eder mi beni? Etmiyor. Mesela hadisi ben çok üzülerek söylüyorum maalesef kaynak olarak kullanamıyorum." kullanamıyorum diyerek ileri sürmüştür. İslam dini bilgisi açısından katılımcılar tarafından ana kaynaklardan biri olarak belirtilen hadis, K2'ye göre dini bilgi için bir kaynak teşkil etmemektedir. K2 bireysel anlamda dini bilgi kaynağı olarak yalnızca vahiy ve aklı esas almaktadır. Sonraki konuşmalarında K2 hadisi dini bilgi noktasında güvenilir bir kaynak olarak görmediğini belirtmiştir. K2'ye sonda soru olarak "hadisleri neden bir bilgi kaynağı olarak görmediği” sorulmuştur. K2 cevap olarak; "Kur'an' c çok fazla okuyorum ve çok fazla çelişkiye düşüyorum” demiştir. Görüldüğü gibi K2 de K3 gibi hadislerin zaman zaman Kur'an ile çelişki doğurduğunu ifade etmiştir. K2 ve K3 hadisler ile ayetler arasında zaman zaman uyumsuzluklar ile karşılaştığı için hadisleri güvenilir bulmadığını ve bireysel anlamda dini bilgi kaynağı olarak başvurmadığını ifade etmiştir. Bu anlamda katılımcılara göre hadisler dini bilgi kaynağı olma noktasında Kur'an kadar tatmin edici bulunmamaktadır.

Dini bilgi kaynağı olarak yalnızca Kur'an'ın tercih edilmesini dini bilgide eksiklik olarak tanımlayan K9 “ilk kaynağımız Kur'an ve sünnet olursa aşamayacağımız problem yok... Kur'an'dan alacağımız cevapları net alamıyoruz hadis olmadığı zaman. O yüzden hadise, 
sünnete ihtiyaç var... Bugün eğer dini bilgi veya İslam ülkelerini ele aldığımız zaman bunun yansıması Müslümanlarda olmuyorsa kaynağının yanlış seçiminden kaynaklanıyor... Hani Muaz ibn Cebel olayını biliyorsunuz..." ifadeleriyle bilgi kavramını dini bilgi ile eşleștirerek bu genellemeyle bütün bilgilerin Kur'an'da yer aldığını belirtmiştir. Buna göre Kur'an insanın aradığı bütün soruların cevabını sayfaları arasında barındırmaktadır. Eğer insan bu cevaplara ulaşamıyorsa burada Kur'an'1 okumada yöntemsel bir hata bulunmaktadır. Bu yaklaşım K9'un dini bilgiye yönelik işlevselci tutumunu ortaya çıkarmaktadır. Çünkü K9'un ifadelerine göre dini bilgi doğru kaynaklar üzerinden okunup anlaşıldığı takdirde dünyevi kalkınmayı da beraberinde getirecektir. Ayrıca Müslümanların bir eksikliği olarak dini bilginin bir diğer kaynağı olan sünnetten yeterince istifade edilmediği ortaya konulmaktadır. Ancak dini bilgi kaynaklarının tercih edilmesinde bir hiyerarşi söz konusudur. K9 bu hiyerarşik sıralamayı Muaz ibn Cebel hadisi olarak bilinen hadisteki sıralama ile anlatmıştır. Bu hadisteki sıralamaya göre İslam'ın ana kaynakları olan Kur'an ve sünnet ile bulunamayan bilgilerde bireylerin kendi akılları ile karar vermeleri önerilmektedir. Verilen bu örnek de dini bilginin dünyevi boyutlardaki işlevini ortaya koymaktadır. K8 “kaynak Kur'an ve sünnet. Ötekilerini sınıflandırırsak ilahi kaynaklı olması bir de ilk önceliği akla uygun olması gibi stralamalar..." cümleleri ile hiyerarşik yapıya dikkat çekmiştir. Katılımcılardan K8 de dini bilgi kaynaklarını K9'da olduğu gibi hiyerarşik bir düzlemde ele almıştır. İslam düşünce geleneğinde dini bilginin analizi noktasında özellikle sünnet için hadis kaynaklarının hadis usulü ilmi ile analizini değil akıl ile eleştiriye tabi tutulmasının gerekliliği belirtilmiştir.

Dini bilgi kaynağı olarak katılımcılar birbirinden farklı pek çok kaynak zikretmiş olsalar da K17 "çünkü bizde bilgiyi çok kaynaktan elde etme yok özellikle dini bilgi anlamında" sözüyle dini bilgi konusunda İslam dini özelinde kaynak olarak zaten çok fazla bir alternatif bulunmadığını belirtmiştir. Katılımcılar dini bilginin kutsallığını vurgulayarak Kur'ancılık temelinde dini bilgiyi değerlendirmişlerdir. Öğretmenlerden bir kısmı İslam düşünce dünyasında sıkça tartışılan "Kur'an bize yeter" söylemine yakın görüşler bildirmiştir. K17 “İkidir. Kur'an-ı Kerim ve Sünnet... Belli başlı bunlardan elde edilir.” görüşü buna örnektir. Görüldüğü gibi din eğitimi öğretmenlerinde dini bilginin kaynağını Kur'an ile sınırlandırma temayülü söz konusudur. K20 öğrencinin bilgiyi aktif olarak alıp zihinsel süreç içerisinde onu yapılandırmasını sağlayacak birincil kaynakları sunduğunu "hangi kaynaklardan beslenir? Yönlendirme yapıyoruz. Kur'an'a ve sünnete bakması gerektiğini, yönlendirici olarak..." diyerek belirtmiştir. Katılımcılardan K20'ye göre sınırlı bir dini bilgi sunulmakta öğrenci bu bilgiyi geliştirmek istediği takdirde kaynaklara ilişkin yönlendirmeler üzerinden dini bilginin yapılandırılması din eğitimini oluşturmaktadır. Programda belirtilen yaklaşım paralelinde, öğrenciye birincil kaynaklar sunularak öğrencinin sahip olduğu bilgilerin yetersizliği öğrencinin kendisine fark ettirilerek oluşturulup konu ile ilgili yeni kaynaklara ve bilgilere ulaşma amacıyla referans noktaları sunulmaktadir. 
Katılımcılara göre dini bilginin kaynağı mutmain edici düzeyde olması önemli bir kriterdir. K11, “Dini bilginin kaynağı Kur'an-ı Kerim'dir ve sonra hadisler ve diğerleri gelir. Íbadetler, ahlaka veya ahiret hayatına dair bütün hayatımıza yön veren...Milletler, eski kavimler bütün bilgiyi ilk önce Kur'an-ı Kerim'den öğreniriz. Daha ayrıntılı olarak baktığımızda hadisler, tefsir, hadis veya siyer alanında yazılmış diğer kaynakları baz alabiliriz." cümleleri ile bilgi ve dini bilgi arasında ilk bilginin Kur'an'dan edinilmesinden dolayı bir fark olmadığını ileri sürmüştür. Katılımcılardan K11, K5 ve K9 dini bilgi ve bilgi kavramlarını eşleştirmiştir. Buna göre Kur'an eskatoloji, tarih, imanî ve itikadî olan bütün alanlar için bir bilgi kaynağıdır. Bu katılımcılar Kur'an'ı yalnızca dini bilginin değil bütün bilgi türlerinin kaynağ1 olarak görmektedirler. Bu bağlamda K11, K5 ve K9 bilgi ve dini bilgiyi birbirinden ayırt etmeden bütüncül yaklaşmaktadır. Hadisler katılımcılar tarafından daha çok dini bilgiye yönelik ele alınırken Kur'an'daki bilgiler daha genel ve bütün hayata yönelik nitelikte bulunmaktadır. K11 hadisler ile birlikte İslam düşünce geleneğine önemli katkılar sunmuş olan tefsirler ve hadis alanlarındaki ikincil kaynak niteliğindeki eserleri de dini bilgi kaynağı olarak değerlendirmektedir.

K4, "bana sorarsanı tefsirde Fahrettin er-Razi, İbn Kesir derim. Ama benim ihtiyacımı belki dirayet tefsiri görecektir, değil mi? Bütün kaynaklardan yararlanabileceğimizi düşünüyorum. Mesela Şatibi çok önemli bir İslam hukukçusudur... ama bazı yorumları var ki dersiniz 'bunu çocuk yapmaz." şeklindeki düşüncesi ile İslam düşünce geleneğinde oldukça önemli olan ve sıkça başvurulan eserleri ve yazarlarını açık bir kutsallıkla okumanın getirebileceği sakıncaları ortaya koymuştur. Burada bilgi kaynağı olarak akıl ön planda tutulmuştur. Ona göre İslam düşünce geleneğinde yer alan dini bilgilerin rasyonel olarak eleştirel bir göz ile ele alınması gerekmektedir. Katılımcılar dini bilgiye ulaşmada kullanılan ikincil, üçüncül nitelikteki kaynaklardaki bilgilerin rasyonel ve İslami açıdan bir bütünlük sergilemesini beklemektedir. Bu yaklaşımın din öğretimi derslerinin diğer branşlar ile uyumsuzluğu ve din-bilim çatışması içerisine girmeyi engelleyebilmektedir. Bu anlamda K4'e göre dini bilginin öğretim süreçlerinde salt fideist ve mistik bir temelde ele alınması bir problem olarak karşımıza çıkmaktadır. Ancak dini bilginin her boyutunun rasyonalist bir tutum ile eleştirel olarak ele alınması da ona karşı pozitivist bir algı geliştirmenin önünü açabilmektedir. Dini bilgi kaynakları İslam sistematiği içerisinde detaylı ve belirgin olarak ortaya konulmuştur.

K1, "klasik usulden gitsek; Kur'an-ı Kerim, Hz. Peygamber'in sünneti, icma, kıyas hatta buna başka başka şeyler de ekliyorlar muamelattan, toplum yararından kamu yararına. Amma velakin Kur'an'da her şeyin özü itibariyle en temel kaynak Kur'an-ı Kerim'in kendisidir." K1'e göre dini bilginin kaynakları klasik fikıh usulünde kullanılan sistem üzerinden özetlenebilir. Hakikatin tek kaynağı Kur'an olmakla birlikte dini bilginin derinleştirilip çeşitlenmesinde beşerî bilginin de önemli bir yeri bulunmaktadır. Katılımcılar dini bilgi edinme noktasında İslam'ın temel kaynaklarını ve İslam düşünce geleneğinde sistemleșen bilginin derinleştirilmesi ve çeşitlendirilmesi yönünde ortaya 
konulan yönteme işaret etmişlerdir. Bu kaynak ve yöntemler öğretmenlerin kendi bireysel yaşamlarındaki dini bilgi kaynakları olarak da belirtilebilir. Denilebilir ki dini bilginin kaynağı yalnızca Kur'an ve sünnet olarak ele alınsa da İslam düşünce geleneğinde yer alan bilgi sistematiği beşerî yönleriyle dini bilgiye katkıda bulunmaktadır. Katılımcılar dini bilgi kaynaklarını Kur’an, sünnet ve İslam düşünce geleneğinde yer alan alanyazın şeklinde sınırlandırmışlardır.

İkincil Kaynaklar: Din eğitimi öğretmenleri, derinlikli bilgi edinme amacı ile akademik metinlere de dini bilgi kaynağı olarak başvurmaktadırlar. Katılımcılar bireysel anlamda dini bilgilerini geliştirmek için güncel dini yayınları ve özellikle akademik alanda yazılan eserleri önemli kaynaklar olarak görmektedirler. "Kuramer'den çıkan kitapların hepsini okudum... Mustafa Öztürk, Ömer Özsoy, Fazlur Rahman. Bu isimlerin tüm kitaplarını okumuşumdur. Ali Bardakoğlu, Mustafa Çağrıcı falan... "Sahabe Döneminde İktidar Kavgası" Ahmet Akbulut, bir tane daha söyleyeyim, Mehmet Azimli'nin Siyeri Farklı okumak, Hz. Ebu Bekir'i Farklı Okumak, Hz. Ömer’i Farklı Okumak..." (K4). K4, İslam düşünce geleneğinde yerleşik olarak kabul edilen bilgileri güncel kaynaklardan da okumaya çalıştığını belirtmiştir. Bunu vermiş olduğu örneklerde görmek mümkündür. K4 yukarıda da belirttiği gibi dini bilginin hem İslam sistematiği hem de rasyonel düzlemde tutarlılık arz etmesi beklentisi içerisindedir. Dini bilgi kaynağı olarak da bu minvalde olan akademik eserleri tercih etmektedir. K4 gelenekte ve güncelde yer alan bir kaynağın dini bilginin öğretim süreçlerine dahil edilebilmesi için eleştirel bir göz ile okunması gerektiğini belirtmektedir. K6, "bilgi, otorite sahibi alanında kimlerdir? Hayrettin Karaman veya Faruk Beşer." cümleleri ile bahsi geçen isimleri referans aldığını belirtmiştir. Katılımcıların dini bilgi kaynağı olarak ana kaynakların dışındaki ikincil kaynaklarda, kendi dini bilgi anlayışları paralelinde kaynakları tercih ettikleri söylenebilir. Burada K4'ün DKAB öğretmeni K6'nın ise meslek dersi öğretmeni olmasının kaynak seçimlerinde etkisinin olabileceği de eklenebilir.

Din eğitimi öğretmenlerinin dini bilgi kaynakları genellikle Kur'an ve sünnet ile sinırlıdır. Ancak Kur'an ve sünnet “yeterli olmadığı zaman araştıralım diyoruz. Diyanet'e başvuruyoruz, üniversitedeki hocalarımızdan bazılarıyla istişare ediyoruz...” K5'e göre Türkiye'de Diyanet İşleri Başkanlığı dini bilgiye yönelik yayın üretmede önemli bir kurumdur. DİB ve yayınları katılımcılar tarafından dini bilgiye kaynak sağlayan bir otorite olarak görülmektedir. "Diyanet'in kaynaklarını kullanıyorum. Dini bilgi olarak eleştirilecek çok yönü olsa da Diyanetin yine çok faydalı olduğunu düşünüyorum. Öyle ya da böyle bir süzgeçten geçmiş bir bilgi...çocuklara da dini bilgi okuyacaksa illa ki bir Diyanet süzgecinin olmasını tavsiye ediyorum..." (K15). K4 ve K15 din öğretiminde kullanmış oldukları dini bilgilerin kaynağına ve bu bilgilerin eleştirel bir göz ile değerlendirilmiş olmasına önem vermektedir. Katılımcılara göre dini bilginin doğru kaynaklardan edinilmesi oldukça önemlidir ve öğretmenlerin bu konudaki hassasiyetleri görülür düzeydedir. K13 “Kur'an-ı Kerim ve hadisleri insanlara anlatma biçimimiz zamanla değişiyor. 0 yüzden bilgi kaynağı olarak alimleri önemsiyorum. Hangi alimleri? Çağımızı anlamış, okumuş, yaşamış...” ifadelerini kullanmıştır. Buna göre din eğitimi öğretmenlerinin 
dini bilgi kaynaklarından biri de ana kaynakları güncel bir zihin ile idrak etmiş ve güncel bir dil ile sunmayı başaran nitelikteki kişilerin eserleri olmalıdır. Çünkü şartlar değiştikçe dini bilginin idraki ve bireylere sunulma şekli de değişmektedir.

K7, "bilgiye günümüzde ulaşmak çok kolay. İnternettir, her yönden çok kolaylikla ulaşıllyor. Temel referansımı Kur'an, hadisler işte o dörtlï silsile var ya Kur'an, hadis, kiyas, icma diye gideriz." cümleleri ile günün getirdiği kolaylık ve imkanlardan yararlandığını ifade etmiştir. Bu anlamda internet dini bilgi açısından da önemli bir kaynak olmaktadır. K10, "ben video izliyorum bununla ilgili işte hani Siyer ile ilgili pek çok video oluyor." K10'a göre internet üzerinden gerçekleştirilen dini bilgi içerikli video ve eğitimler önemli bir kaynaktır. Ayrıca internet üzerinden kullanılan kaynaklar farklı kaynakları keşfetmeyi de sağlamaktadır. Din eğitimi öğretmenlerinin Kur'an, sünnet ve İslam düşünce geleneğinde yer alan eserlerin yanında bireysel olarak beslendikleri kaynaklardan biri de internet ortamında sunulan dini bilgi içerikli dersler ve videolardır. "Mesela Klasik Düşünce Okulu diye bir şey var. Fıkıh, İslam Hukuku gördük ama ne kadar eksik olduğumu orada anladım." şeklinde birçok benzer ifadeleri dile getirdikleri tespit edilmiştir. K10 ilahiyat eğitimi sırasında aldığı derslerdeki eksikliği internet üzerinden sunulan bu videolarda fark ettiğini belirtmiş̦tir. K10'nun ifadeleriyle din eğitimi öğretmenlerinin alan bilgilerine dair eksikliklerini zaman zaman internet kanalıyla giderdikleri ortaya konulmuştur. Din eğitimi öğretmenleri Kur'an ve sünnet gibi birincil kaynaklara başvurma noktasında vurgu yapmakla birlikte ikincil kaynakları da dini bilgi edinmede kaynak olarak kullanmaktadırlar. Din eğitimi öğretmenlerinin internetteki mecraları ve sosyal medyayı dini bilgide eksikliklerini giderebilecekleri bir kaynak olarak görmektedir. Din eğitimi öğretmenlerinin bu tercihlerinin Demir tarafından din eğitimi öğretmen adaylarına yönelik çalışması ile paralel sonuçlar içermektedir. ${ }^{26}$

Bu kategoriye ilişkin genel bir değerlendirme yapılacak olursa; katılımcılar dini bilginin geçerli kaynağını yine Kur'an ve sünnet olarak ana kaynaklar üzerinden ortaya koymuşlardır. Ayrıca dini bilgi İslam düşünce geleneğinden ayrı değerlendirilmemiştir. Burada geleneğe atfedilen açık kutsallıktan kaynaklı bir yaklaşımdan dolayı öğretmenler kendi düşüncelerini açıkça ifade etmemiş de olabilir. Katılımcılar Kur'an dışındaki kaynakları açık bir şekilde reddetmemekle birlikte dini bilgi alanında hadis ve diğer kaynakları da Kur'an ışı̆̆ında değerlendirmek gerektiğini belirtmişlerdir. Bu bağlamda din eğitimi öğretmenlerinde dini bilginin kaynaklarını Kur'an ile sınırlandırma temayülü söz konusudur. Dini bilgiye ilişkin farklı kaynakların kullanılmasına tereddütle yaklaşılmasının nedenini dini bilginin ele alınmasında ortaya çıkan farklı yöntemlerin farklı çıkarımlara neden olması gösterilmiştir. Dini bilgiye bu düzeyde metin merkezli yaklaşımın din öğretimi derslerine yansımasının olabileceği düşünülmektedir.

26 İsmail Demir, Dini Bilgi Edinme Kaynağı Olarak Sosyal Medya (İlahiyat Fakültesi Öğrencileri Örneği) (Çanakkale Onsekiz Mart Üniversitesi Sosyal Bilimler Enstitüsü Felsefe ve Din Bilimleri Anabilim Dalı, Doktora Tezi, 2019). 
Katılımcılar için dini bilgi kaynaklarından ikincil kaynak niteliğindeki dini yayınlar da önem taşımaktadır. Ancak burada DİB’in yayınları veya akademik eserler daha çok belirtilmiştir. Bunun nedeni din eğitimi öğretmenlerinin dini bilginin kaynaklarında bilimsel süzgeçler tercih etmesi olabileceği gibi yakın zamanda Türkiye'de cemaat ve cemaat liderlerine ilişkin yaşanan tecrübelerin bu gruplar tarafindan ortaya konulan kaynaklara karşı duyulan güvensizlik de olabilmektedir. Bu anlamda katılımcılar ikincil ve üçüncül nitelikteki dini bilgi kaynaklarına karşı mesafeli bir tutum sergilemişlerdir. Katılımcılar dini bilgi edinirken ve öğretirken kaynaklarda oldukça seçici davranmaktadır. Bunu öğrencilerine de önermektedirler. Katılımcıların dini bilgi kaynaklarına ilişkin bu tutumları dini bilginin hassasiyetle yaklaşılması gereken bir alan olduğunu vurgulamıştır. Bu anlamda dini bilginin bilgi kirliliğinden arınmış olması önem arz etmektedir. Çünkü katılımcılara göre dini bilgi yanlış kaynaklardan yanlış bir algı ve anlayış ile öğrenildiği ve öğretildiği zaman birbirinden oldukça farklı dini yaklaşım ve tutumlara kaynaklık edebilmektedir. Bununla birlikte katılımcıların bu yaklaşımları, dini bilgi konusunda güçlü bir kavrayışa sahip olamadıkları için sağduyudan uzaklaşmadan, resmî söylemler çerçevesinde kalmayı tercih ettikleri şeklinde de değerlendirilebilir.

\section{Sonuç ve Tartışma}

Din eğitimi öğretmenlerinin görüşleri ile bilgi ve dini bilgi anlayışlarının ortaya konulmaya çalışıldığı bu araştırmada din eğitimi öğretmenlerinin yalnızca bilgi ve dini bilgiye ilişkin görüşlerine değinilmiştir. Katılımcılar insanın yaşamak için bilgiye muhtaç olduklarını bilginin yaşamın kendisi olduğu düşüncesi ile ortaya koymuşlardır. Bunu ifade ederken katılımcılar, bilgi ve hayat kavramlarını özdeşleştirmişlerdir. Ancak bazı katılımcılar bilgi ifadesinden bilimsel bilgiyi kastetmişlerdir. Katılımcılarda bütüncül bir bilgi anlayışı söz konusudur. Ayrıca beşerî bilgi de dini bilgiye dâhildir. Öğretmenlerdeki bu bütüncül yaklaşımın bilgi ve dini bilgiyi kendi inançları temelinde değerlendirmiş olmalarından kaynaklanabileceği düşünülmektedir. Bilginin kaynağı olarak katılımcılar manevi, aşkınsal ve bütüncül bir yaklaşım sergilerken bilginin işlevselliği noktasında dini bilgiyi bilgiden ayıran katılımcılar da bulunmaktadir.

Katılımcıların bilgi ve dini bilgiyi ilim - amel ilişkisi bağlamında ele alınmış olduğu söylenebilir. Zira öğretmenler bilgi ve dini bilgi konusunda öncelikle bilişsel boyutlara vurgu yapmışlar, sonrasında ise uygulamaya/hayata yansımasının gerekliliğini ifade etmişlerdir. Buna göre din eğitimi öğretmenlerinin bilgi konusunda mutlak olarak uygulamaya dönüşme beklentileri bulunmaktadır. Bu yaklaşım aynı zamanda katılımcıların öğrenme anlayışını da yansıtmaktadır. Öğretmenler değerlendirmelerini eğitim ve öğretim kavramları üzerinden ifade etmişlerdir. Bu açıdan öğretmenlerin eğitimi içselleştirerek öğretmen kimlikleri ile bilgi ve din bilgiyi değerlendirdikleri söylenebilir. Katılımcıların bilgiye epistemolojik açıdan spiritüalist ve idealist yaklaşımları varken aksiyoloji açısından idealist yaklaşımları bulunmaktadır. Bu 
idealist yaklaşımı üst düzey düşünme becerilerinde farklı açılardan sınılandırıcı unsurların etkisi ile ortaya çıktığı da düşünülebilir. Ayrıca bu yaklaşımlarının bilgi tanımlamalarının üretim kavramından uzak olarak büyük ölçüde sağduyu ekseninde ele almalarına da neden olduğu söylenebilir.

Katılımcıların bilgi ve dini bilgi anlayışlarının insan hayatına olumlu katkılar sunan bir araç şeklindedir. Bu durum bilgi ve dini bilginin işlevselliğine dikkat çekmiştir. Bu işlevsellik daha çok değerler, ahlak ve düzen boyutlarında yoğunlaşmıştır. Katılımcılara göre bilginin ve dini bilginin en büyük işlevi hakikate götüren bir araç olması yönüyledir. Dini bilgiyi bilgiden ayıran katılımcılar daha çok manevi bilimler ve pozitif bilimler yaklaşımı ile bu ayrımı açıklamışlardır. Ayrıca bilgi ve dini bilgi kavramlarını birbirinden ayrı gören katılımclar dini bilginin normatif ve dogmatik yönüne vurgu yapmışlardır. Bu noktada dini bilgiye ilişkin ifadelerde dini bilginin daha çok normatifliği ve yaptırım gücü ön plana çıkarılmıştır.

Katılımcılar bilgi ve dini bilgiye kaynaklar açısından vurgu yapmışlardır. Onlara göre bilgi ve dini bilgi kavramlarının en çok ayrıştığı nokta da burasıdır. Öğretmenlerin zaman zaman yalnızca Kur'an'ı kaynak olarak görmelerini Kur'ancılık söylemleri ile paralel görülebilir. Katılımcılara göre din eğitiminin dinsel yönü vahiy ile çevrilidir. Öğretmenler öğretim süreçlerinde Kur'an ve sünneti kaynak olarak belirtirlerken bireysel olarak beslendikleri dini bilgi kaynaklarını; birincil, ikincil kaynaklar ve sosyal medya, şeklinde değişmektedir. İkincil kaynaklarda özellikle Diyanet'in kaynaklarının dışına çıkmamayı tercih etmelerini bilginin içsel yapısındaki etken unsurların çeşitliliği ve yoruma açıklıktan kaçınma olarak ele alınabilir. Bu anlamda katılımcılar din öğretiminde konunun uzmanları tarafından sınırları net olarak belirlenen "nesnel" düzlemdeki dini bilgileri tercih ettikleri çıkarımında bulunulabilir. Katılımcıların öğretim süreçlerinin dışında bilgi kavramını felsefi bir temelde değil, dini bir temelde değerlendirdikleri söylenebilir. Ayrıca öğretmenler, bilgi ve dini bilgi anlayışlarını İslam bilgi sistemi içerisinde ortaya koymuşlardır.

Katılımcıların görüşlerine göre din eğitimi öğretmenleri bilgi ve dini bilgiye İslam bilgi nazariyesi çerçevesinde yaklaşmaktadırlar. Bu bağlamda katılımclar bütün bilgileri Allah'a isnat ederek bütüncül bir bilgi anlayışına sahip olsalar da bu bütüncül anlayış daha çok kaynaklar açısından vurgulanmıştır. Ancak dini bilginin işlevi ve hayata yansıması noktasında katılımcılar bilgiyi dini bilgiden ayırmışlardır. Katılımcılar, teorik düzlemde bilgi ve dini bilgiyi birbirinden ayırmama konusunda İslam bilgi anlayışı paralelinde bir bilgi anlayışı ortaya koymuşlardır. Ancak bu bütünlüğün eğitim sisteminin tamamında beklenilmesi söz konusudur. Bu yaklaşımın dini bilgi ve bilgi kavramlarının ayrı tutulmamasını da açıkladığı gibi bireylerde var olan inancın bilgi değeri taşıdığı sonucuna ulaştırması da mümkündür. Katılımcılardaki bilgiye yönelik bu bütüncül yaklaşımın dini bilgi çatısı altında geliştiği ve öğretmenlerin aslında dini bilgi anlayışlarının bilgi anlayışlarını da kapsayıcı nitelikte olduğunu göstermektedir.

Sonuç olarak dini bilgi, katılımcılar tarafından eğitime konu olan ve pedagojiye ihtiyaç duyulan bir bilgi olmaktan öte bireylere dünya görüşü kazandıran bir bilgi 
olarak görülmektedir. Her ne kadar öğretmenler genel olarak bilgiye bütüncül bir yaklaşım sergileseler de dini bilgiyi değer taşıması nedeniyle daha üstün bir konumda görmektedirler. Bu anlayışın daha çok bilginin işlevselliği bağlamında ortaya çıktığ1 söylenebilir. Katılımcılara göre dini bilgi teorik düzlemi kadar pratik düzlemde de önem arz etmektedir. Katılımcıların dini bilgiye ilişkin bu yaklaşımlarının öğretim süreçlerindeki alan bilgilerini etkilediği ve süreçleri yönlendirdiği muhtemeldir. Öğretmenlerin ne öğretecekleri sınırları ve içerikleri ile birlikte "nesnel” bir bilgi formülünde belirlenmiş olması beklentisi bulunmaktadır. Dini bilgiye ilişkin bu yaklaşım onun öğretimi sürecinde de tek tip bir dini bilgi anlayışı ile öğretim yöntem, teknik ve stratejilerinin kullanımını getirebilmektedir.

Öğretmenlerin bilgi ve dini bilgi anlayışlarını kendi görüşleri üzerinden değerlendirmek önemli olmakla birlikte öğretmenlerin bu anlayışlarının; öğrenciler ile iletişimlerine, ders süreçlerine, tercih etmiş oldukları öğretim yöntem ve tekniklerine, kullanmış oldukları din diline nasıl yansıdığını ortaya çıkarmanın çalışmayı daha anlamlı kılacağı düşünülmektedir. Bu anlamda çalışma din eğitimi öğretmenlerinin dini bilgi anlayışlarının hangi düzlemde olduğu ve öğretim süreçlerine nasıl yansıdığına yönelik çalışmalarla desteklenmeye muhtaçtır.

Ek 1: Çalışma Grubuna Ait Bilgiler

\begin{tabular}{|c|c|c|c|c|c|c|}
\hline Rumuz (K) & & Cinsiyet & Yaş & $\begin{array}{l}\text { Öğrenim } \\
\text { Durumu }\end{array}$ & Görev & $\begin{array}{l}\text { Mesleki } \\
\text { Deneyim } \\
\text { (yil) }\end{array}$ \\
\hline $\begin{array}{l}\text { Kat1lımc1 } \\
\text { (K1) }\end{array}$ & 1 & K & 32 & Lisans & $\begin{array}{l}\text { DKAB Öğ- } \\
\text { retmeni }\end{array}$ & 8 \\
\hline $\begin{array}{l}\text { Katılımc1 } \\
\text { (K2) }\end{array}$ & 2 & K & 39 & Lisans & $\begin{array}{l}\text { DKAB Öğ- } \\
\text { retmeni }\end{array}$ & 5 \\
\hline $\begin{array}{l}\text { Katılımc1 } \\
\text { (K3) }\end{array}$ & 3 & E & 51 & Lisans & $\begin{array}{l}\text { DKAB Öğ- } \\
\text { retmeni }\end{array}$ & 28 \\
\hline $\begin{array}{l}\text { Katilımc1 } \\
\text { (K4) }\end{array}$ & 4 & E & 54 & Lisans & $\begin{array}{l}\text { DKAB Öğ- } \\
\text { retmeni }\end{array}$ & 31 \\
\hline $\begin{array}{l}\text { Katılımc1 } \\
\text { (K5) }\end{array}$ & 5 & E & 56 & Lisans & $\begin{array}{l}\text { Meslek dersi } \\
\text { öğretmeni }\end{array}$ & 33 \\
\hline $\begin{array}{l}\text { Katılımc1 } \\
\text { (K6) }\end{array}$ & 6 & E & 26 & Lisans & $\begin{array}{l}\text { Meslek dersi } \\
\text { öğretmeni }\end{array}$ & 2 \\
\hline $\begin{array}{l}\text { Katılımc1 } \\
\text { (K7) }\end{array}$ & 7 & $\mathrm{E}$ & 36 & Yüksek lisans & $\begin{array}{l}\text { Meslek dersi } \\
\text { öğretmeni }\end{array}$ & 4 \\
\hline $\begin{array}{l}\text { Katılımc1 } \\
\text { (K8) }\end{array}$ & 8 & K & 32 & Lisans & $\begin{array}{l}\text { Meslek dersi } \\
\text { öğretmeni }\end{array}$ & 7 \\
\hline $\begin{array}{l}\text { Katılımc1 } \\
\text { (K9) }\end{array}$ & 9 & E & 55 & Lisans & $\begin{array}{l}\text { Meslek dersi } \\
\text { öğretmeni }\end{array}$ & 35 \\
\hline $\begin{array}{l}\text { Katılımc1 } \\
\text { (K10) }\end{array}$ & 10 & K & 40 & 2 Lisans/ILITAM & $\begin{array}{l}\text { Meslek dersi } \\
\text { öğretmeni }\end{array}$ & 2 \\
\hline $\begin{array}{l}\text { Katılımc1 } \\
\text { (K11) }\end{array}$ & 11 & K & 27 & Lisans & $\begin{array}{l}\text { Meslek dersi } \\
\text { öğretmeni }\end{array}$ & 2 \\
\hline
\end{tabular}




\begin{tabular}{|c|c|c|c|c|c|c|}
\hline $\begin{array}{l}\text { Katılımc1 } \\
\text { (K12) }\end{array}$ & 12 & $E$ & 56 & Lisans & $\begin{array}{l}\text { Meslek dersi } \\
\text { öğretmeni }\end{array}$ & 33 \\
\hline $\begin{array}{l}\text { Katılımc1 } \\
\text { (K13) }\end{array}$ & 13 & E & 32 & Lisans & $\begin{array}{lr}\text { Meslek ve } & \text { vKAB Öğ- } \\
\text { retmeni } & \end{array}$ & 8 \\
\hline $\begin{array}{l}\text { Katılımc1 } \\
\text { (K14) }\end{array}$ & 14 & E & 25 & Lisans & $\begin{array}{l}\text { DKAB Öğ- } \\
\text { retmeni }\end{array}$ & 1 \\
\hline $\begin{array}{l}\text { Katılımc1 } \\
\text { (K15) }\end{array}$ & 15 & $E$ & 34 & 2 Lisans/ILITAM & $\begin{array}{l}\text { DKAB Öğ- } \\
\text { retmeni }\end{array}$ & 2 \\
\hline $\begin{array}{l}\text { Katılımc1 } \\
\text { (K16) }\end{array}$ & 16 & E & 39 & Lisans & $\begin{array}{l}\text { DKAB Öğ- } \\
\text { retmeni }\end{array}$ & 15 \\
\hline $\begin{array}{l}\text { Katılımc1 } \\
\text { (K17) }\end{array}$ & 17 & K & 27 & Lisans & $\begin{array}{l}\text { DKAB Öğ- } \\
\text { retmeni }\end{array}$ & 3 \\
\hline $\begin{array}{l}\text { Kat1lımc1 } \\
\text { (K18) }\end{array}$ & 18 & E & 36 & Lisans & $\begin{array}{l}\text { DKAB Öğ- } \\
\text { retmeni }\end{array}$ & 10 \\
\hline $\begin{array}{l}\text { Katılımc1 } \\
\text { (K19) }\end{array}$ & 19 & K & 26 & Lisans & $\begin{array}{l}\text { DKAB Öğ- } \\
\text { retmeni }\end{array}$ & 3 \\
\hline $\begin{array}{l}\text { Katılımc1 } \\
\text { (K20) }\end{array}$ & 20 & E & 30 & Lisans & $\begin{array}{l}\text { DKAB Öğ- } \\
\text { retmeni }\end{array}$ & 4 \\
\hline $\begin{array}{l}\text { Katılımc1 } \\
\text { (K21) }\end{array}$ & 21 & K & 43 & Lisans & $\begin{array}{l}\text { DKAB Öğ- } \\
\text { retmeni }\end{array}$ & 3 \\
\hline
\end{tabular}

\begin{tabular}{|c|c|}
\hline Etik Beyan / Ethical Statement & $\begin{array}{l}\text { Bu çalışmanın hazırlanma sürecinde bilimsel ve } \\
\text { etik ilkelere uyulduğu ve yararlanılan tüm çalış- } \\
\text { maların kaynakçada belirtildiği beyan olunur / It } \\
\text { is declared that scientific and ethical principles have } \\
\text { been followed while carrying out and writing this } \\
\text { study and that all the sources used have been properly } \\
\text { cited. }\end{array}$ \\
\hline Yazar(lar) / Author(s) & Cemal Tosun - Gülşen Sayın \\
\hline Finansman / Funding & $\begin{array}{l}\text { Yazarlar, bu arastırmavı desteklemek icin her- } \\
\text { hangi bir dıs fon almadıklarını kabul ederler / } \\
\text { The authors acknowledge that thev received no } \\
\text { external funding in support of this research. }\end{array}$ \\
\hline Yazar Katkilar1 / Author Contributions & $\begin{array}{l}\text { Calısmanın Tasarlanması / Conceiving the Study: } \\
\text { CT (\%45), GS (\%55) } \\
\text { Veri Toplanması / Data Collection: CT (\%20), GS (\%80) } \\
\text { Veri Analizi / Data Analvsis: CT (\%20), GS (\%80) } \\
\text { Makalenin Yazımı / Writing up: CT (\%20), GS } \\
\text { (\%80) } \\
\text { Makale Gönderimi ve Revizvonu / Submission } \\
\text { and Revision: CT (\%55), GS (\%45) }\end{array}$ \\
\hline Çıkar Çatışması / Competing Interests & $\begin{array}{l}\text { Yazarlar, cıkar catısması olmadığını bevan eder- } \\
\text { ler / The authors declare that they have no } \\
\text { competing interests. }\end{array}$ \\
\hline
\end{tabular}




\section{Kaynakça}

Acar, Rahim. "Dinî Çeşitliliği Değerlendirme Yetkisi: Frithjof Schuon Örneği”. Marmara Üniversitesi İlâhiyat Fakültesi Dergisi 44/1 (2013), 99-122.

Açıkgenç, Alparslan. “İslam Bilgi Nazariyesi”. İslam’a Giriş. ed. Bünyamin Erul. Ankara: Diyanet İşleri Başkanlığı Yayınları, 2007.

Açıkgenç, Alparslan. İslâm Medeniyetinde Bilgi ve Bilim. İstanbul: İSAM Yayınları, 2006.

Blackstone, William T. Dinsel Bilgi Sorunu: Felsefi Çözümlemelerin Dinsel Bilgi Sorununa Etkileri. çev. Tuncay İmamoğlu. İstanbul: Ataç Yayınları, 2005.

Burke, Peter. Bilgi Tarihi Nedir?. çev. Turgay Sivrikaya. İstanbul: Islık Yayınları, 2018.

Cevizci, Ahmet. Eğitim Felsefesi. İstanbul: Say Yayınları, 2016.

Daud, W. M. Nor Wan. İslam bilgi Anlayışı ve Çoğulcu Bir Toplumun Eğitim Sistemine Yansıması Malezya Örneği. çev. Fuat Aydın. Ankara: Ankara Okulu Yayınları, 2002.

Demir, İsmail. Dini Bilgi Edinme Kaynağı Olarak Sosyal Medya (İlahiyat Fakültesi Öğrencileri Örneği). Çanakkale Onsekiz Mart Üniversitesi Sosyal Bilimler Enstitüsü Felsefe ve Din Bilimleri Anabilim Dal, Doktora Tezi, 2019.

Foucault, Michel. Bilme İstenci Üzerine Dersler Collège de France Dersleri. çev. Kerem Eksen, İstanbul: İstanbul Bilgi Üniversitesi Yayınları, 2016.

Groome, Thomas H. What Makes Us Catholic Eight Gifts for Life. PDF: Harper Collins e-book, 2001.

Gutek, Gerald Lee. Eğitimde Felsefi ve İdeolojik Yaklaşımlar. Ankara: Ütopya Yayınevi, 3. Basım, 2019.

Güngör, Erhan (ed. ). Çağdaş Epistemolojiye Giriş. İstanbul: İnsan Yayınları, 2011.

Hick, John. Faith and Knowledge. Hong Kong: The Macmillan Press, 1967.

King, Ursula. "Historical and Phenomenological Approaches" Contemporary Approaches to The Study of Religion, ed. Frank Whaling. New York, Amsterdam: Mouton Publishers, 1984.

Kur'an-ı Kerim ve Elmalılı Meâli, çev. Mustafa Özel. İzmir: Akit Yayınları, 2011.

Patton, Micheal Quinn. Nitel Araştırma ve Değerlendirme Yöntemleri. çev. Mesut Bütün - Selçuk Beşir Demir. Ankara: Pegem Akademi Yayıncılık, 2. Basım, 2018.

Peterson, Michael vd. Akıl ve İnanç: Din Felsefesine Giriş. İstanbul: Küre Yayınları, 2015.

Quine, W. V. - Ullian, J. S. Bilgi Ağı. çev. A. Hadi Adanalı. Ankara: Kitabiyat Yayınları, 2001.

Reçber, Mehmet Sait. "Dini İnanç ve Dini Bilgi Kavramları Üzerine”. Diriliş Yolunda Türk Düşüncesi Necati Öner'e Armağan. ed. Bahaeddin Yediyıldız. Ankara: Türk Kültürünü Araştırma Enstitüsü Yayınları, 2013.

Tosun, Cemal. Din Eğitimi Bilimine Giriş. Ankara: Pegem Akademi Yayınları, 7. Basım, 2012.

Uslu, Ferit. Felsefi Açıdan İmanı Temellendirme. Ankara: Ankara Okulu Yayınları, 2004.

Uyanık, Mevlüt. Bilginin İslamileştirilmesi ve Çağdaş İslam Düşüncesi. Ankara: Ankara Okulu Yayınları, 3. Basım, 2014.

Walshe, Karen - Teece, Geoff. “Understanding 'Religious Understanding' in Religious Education”. British Journal of Religious Education 35/3 (Eylül 2013), 313-325. 